Author version: Earth Planet. Sci. Lett.: 285(1-2); 2009; 179-189

\title{
Indian Ocean Circulation and Productivity during the Last Glacial Cycle
}

Alexander M. Piotrowski ${ }^{1 *}$, Virupaxa K. Banakar ${ }^{2}$, Adam E. Scrivner ${ }^{1}$, Henry Elderfield $^{1}$, Albert Galy ${ }^{1}$ and Aileen Dennis ${ }^{1}$

1- Godwin Laboratory for Palaeoclimate Research

Department of Earth Sciences, Cambridge University, Cambridge, CB4 2TY, United Kingdom

2- National Institute of Oceanography

(Council of Scientific and Industrial Research)

Dona Paula, Goa-403 004, India

Wordcount: abstract 297, body text 6880, 74 refs, 7 figures, 4 tables.

* Corresponding Author (apio04@esc.cam.ac.uk)

In prep for submission to Earth and Planetary Science Letters 


\begin{abstract}
The Indian Ocean is an important part of the global thermohaline circulation system, receiving deep waters sourced from the Southern Ocean and being the location of upwelling and surface-ocean current flow, which returns warm and salty waters to the Atlantic. It is also an ideal location to reconstruct the link between thermohaline circulation and deep-water nutrient contents. No mixing occurs between major deep-water masses along flow paths within the Indian Ocean, so changes in water-mass provenance reflect changes in deep-ocean circulation while nutrient contents reflect addition and dissolution of organic matter. We present neodymium (Nd) and carbon (C) isotope records, proxies of water-mass provenance and nutrient contents, respectively, from an equatorial Indian Ocean core (SK129-CR2) spanning the last 150 kyr. The Nd isotope record shows that an increased proportion of North Atlantic Deep Water (NADW) reached the Indian Ocean during interglacials (marine isotope stages, MIS 1 and 5), and a reduced proportion during glacials (MIS 2, 4, and 6), and also that changes occurred during MIS 3. The magnitude and timing of deglacial and some MIS 3 variability is very similar to those in the RC11-83/TNO57-21 South Atlantic deep Cape Basin Nd isotope record, suggesting that Atlantic meridional overturning circulation changes were effectively propagated from the southeastern Atlantic into the central Indian Ocean via the Southern Ocean. Comparison of the $\mathrm{Nd}$ and $\mathrm{C}$ isotope records shows that deep-ocean circulation was decoupled from nutrient-content changes on glacial-interglacial timescales, in particular suggesting higher productivity during MIS 5. Increased equatorial productivity during MIS 5 is supported by benthic infaunal-epifaunal foraminiferal $\delta^{13} \mathrm{C}$ gradients, as well as benthic foraminiferal $\delta^{13} \mathrm{C}$ gradients along deep-water flow. Concurrent warming, indicated by planktonic foraminiferal $\mathrm{Mg} / \mathrm{Ca}$ during MIS 5 at the site is consistent with changing thermocline temperature and may indicate a link to surface-ocean hydrographic changes.
\end{abstract}




\section{Introduction}

Reconstructing past changes in global thermohaline ocean circulation (THC) is critical to our understanding of global and regional paleoclimate changes. In the modern global ocean circulation system, likened to a conveyor belt, deep-water masses, which are formed in the subpolar North Atlantic and in the circum-Antarctic, ventilate the entire deep ocean, while surface currents return warm waters from the Pacific and Indian Oceans to the Atlantic. Global THC changes are expected to be closely linked to past climate change (Broecker and Denton, 1989; Ganopolski and Rahmstorf, 2001; Stocker, 2000). Surface-ocean currents transport heat and salt meridionally and between different ocean basins, directly affecting regional climate (e.g. Gulf Stream in the Atlantic, El Nino in the Pacific) and may modulate deep-water formation rates. The deep ocean is the largest dynamic reservoir of carbon dioxide $\left(\mathrm{CO}_{2}\right)$, so past changes in deep-ocean ventilation and structure were important controls on past atmospheric $\mathrm{CO}_{2}$ concentration (Sigman and Boyle, 2000).

Many of the studies which have reconstructed past changes in deep-ocean circulation have used nutrient-based proxies such as benthic foraminiferal $\delta^{13} \mathrm{C}$ and $\mathrm{Cd} / \mathrm{Ca}$, and have focused predominantly on the deep Atlantic (Boyle, 1995; Curry and Oppo, 2005). However, the deep Atlantic corresponds to less than $25 \%$ of the global deep ocean by volume, so any estimate of the carbon storage capacity of the deep ocean must include the relative proportion of Atlantic sourced waters in the Indian and Pacific basins. Another limiting factor of our current understanding of the role of ocean circulation in the climate system is the multiple controls of nutrient-based proxies of deep-ocean circulation. In addition to changes in water-mass mixing, nutrient-based proxies are controlled by changes in export productivity and pre-formed nutrient contents of a water mass. Along with $\mathrm{C}$ isotopic fractionation during air-sea $\mathrm{CO}_{2}$ exchange, these factors likely cause disagreement between the different nutrient proxy records, such as benthic foraminiferal $\delta^{13} \mathrm{C}$ and $\mathrm{Cd} / \mathrm{Ca}$ in the South Atlantic and Southern Oceans (Boyle and Keigwin, 1985; Charles and Fairbanks, 1992; Charles et al., 1996; Lea, 1995; Lynch-Steiglitz

and Fairbanks, 1994; Mackensen et al., 1996; Rickaby et al., 2000). The combination of slower flow speeds with higher productivity and regenerated nutrient contents in the Indian and Pacific Oceans has the potential to cause ambiguity when interpreting whether nutrient proxy records 
(Naqvi et al., 1994; Waelbroeck et al., 2006) reflect changes in deep-water nutrient contents or water-mass circulation.

This problem necessitates a more conservative proxy for deep-water mass provenance and water-mass mixing. Neodymium isotopes $\left({ }^{143} \mathrm{Nd} /{ }^{144} \mathrm{Nd}\right.$; expressed in $\varepsilon_{\mathrm{Nd}}$ notation which is $\left[{ }^{143} \mathrm{Nd} /{ }^{144} \mathrm{Nd}_{\text {Sample }} /{ }^{143} \mathrm{Nd} /{ }^{144} \mathrm{Nd}_{\text {bulk Earth }}-1\right] \times 10^{4}$, where ${ }^{143} \mathrm{Nd} /{ }^{144} \mathrm{Nd}_{\text {bulk Earth }}=0.512638$ (Jacobsen and Wasserburg, 1980); vary between deep-water masses of different provenance. The Nd isotopic composition of most seawater is lower than that of the bulk Earth, suggesting a primary contribution from the continental crust. The $\varepsilon_{\mathrm{Nd}}$ of deep-ocean water ranges from -14 in the North Atlantic, with Nd derived from the ancient Canadian Shield, to -4 in the Pacific, which reflects a greater mantle-derived component from volcanic material (Frank, 2002; van de Flierdt et al., 2004). Seawater Nd isotope compositions in modern deep-ocean water follow the pattern of deep-water flow and correlate well with conservative water-mass proxies, such as salinity, suggesting quasi-conservative behavior controlled by deep-water mass mixing (Goldstein and Hemming, 2003). Neodymium isotopes can be used to reconstruct water-mass provenance and transport because the mean ocean residence time of $\mathrm{Nd}$ ( 700 yr; (Tachikawa et al., 2003; Tachikawa et al., 1999a) is shorter than the mixing time of the deep ocean. This results in individual water masses having distinctive $\mathrm{Nd}$ isotopic compositions which can be traced around the modern deep ocean in seawater data (Goldstein and Hemming, 2003). Unlike stable isotopes and nutrient proxies, radiogenic isotopes such as $\mathrm{Nd}$ are less sensitive to low-temperature and biological processes, because any fractionation of $\mathrm{Nd}$ isotopes is erased by mass-fractionation correction during isotope analysis on the mass spectrometer. Instead, $\mathrm{Nd}$ isotopes are useful as provenance tracers, and can be considered a conservative water-mass tracer of deep-water circulation, as long as $\mathrm{Nd}$ from a different source is not added to the deep water along its flow path. Some seawater studies (Jeandel et al., 1995; Lacan and Jeandel, 2005; Lacan, 2004) and models (Arsouze et al., 2007) have suggested that there is significant exchange of Nd between sediments and seawater, especially along the margins of oceanic basins. Other models argue against significant margin exchange controlling the global oceanic distribution of $\mathrm{Nd}$ isotopes (Jones et al., 2008). Modern cycling of $\mathrm{Nd}$ in the ocean, and potential changes in this during the glacial, will be examined in this paper, in the context of our record and its comparison to other deep-ocean $\mathrm{Nd}$ isotope records. 
A high-resolution $\varepsilon_{\mathrm{Nd}}$ record from site TNO57-21 in the deep South Atlantic shows changes interpreted as more NADW being exported to the Southern Ocean during interglacials and major Greenland interstadials, and less NADW reaching the South Atlantic during glacials and Heinrich stadials (Piotrowski, 2004; Piotrowski et al., 2005; Piotrowski et al., 2008). Important differences exist in $\varepsilon_{\mathrm{Nd}}$ and $\delta^{13} \mathrm{C}$ records from the deep Cape Basin (Piotrowski et al., 2005; Piotrowski et al., 2008), suggesting that the $\delta^{13} \mathrm{C}$ of deep water in the deep South Atlantic changed independently of ocean circulation during glacial-interglacial transitions (Piotrowski et al., 2005) and during MIS interstadial-stadial events (Piotrowski et al., 2008). If the Nd isotopes are primarily responding to water-mass mixing changes, then the $\delta^{13} \mathrm{C}$ changes which are not supported by similar shifts in $\mathrm{Nd}$ isotopes can be interpreted as changes in deep-water $\delta^{13} \mathrm{C}$ composition independent of circulation, resulting from climate-dependant changes in either biological productivity, the pre-formed $\delta^{13} \mathrm{C}$ of a water mass by biological productivity, or air-sea gas exchange of carbon dioxide. Overprints on nutrient-based proxies become even more important in regions of sluggish overturning of bottom water and overlying high biological productivity regimes. In such situations a more conservative proxy, such as Nd isotopes, is needed for accurate reconstruction of past deep-water circulation. The sensitivity of $\mathrm{Nd}$ isotopes in tracing the provenance of water masses, when combined with proxies controlled by climate and biology in addition to circulation, should allow extraction of records of nutrient content and water-mass mixing. Here we utilize $\mathrm{Nd}$, along with nutrient and paleotemperature proxies to examine changes in deep-ocean circulation and nutrient storage, surface-ocean productivity and sea-surface temperatures (SST) in the Indian Ocean during the last glacial cycle.

\section{The Indian Ocean}

Reconstructing the deep-water structure of the Indian Ocean is important for constraining deep-ocean $\mathrm{CO}_{2}$ storage capacity. For example, porewater salinity measurements have been interpreted to show that the Atlantic sector of the glacial Southern Ocean was filled with a dense, southern-sourced, nutrient-rich water mass (Adkins et al., 2002), suggesting a nearly isolated reservoir for $\mathrm{CO}_{2}$ (Sigman and Boyle, 2001). If a southern-derived nutrient-rich water mass substantially filled the glacial deep Indian Ocean, replacing nutrient-poor water sourced from the North Atlantic, the deep ocean's capacity as a carbon reservoir would be increased. Additionally, 
changes in the upwelling of nutrient-rich waters in the Indian Ocean during the last glacial cycle could play a key role in the dynamics of glacial-interglacial nutrient cycling and atmospheric $\mathrm{CO}_{2}$ concentration. Neodymium isotopes may allow us to reconstruct the relative proportion and lateral extent of northern- and southern-derived water in the Indian Ocean.

The Indian Ocean is geographically situated mid-way within the extent of the global THC, between deep-water formation in the Atlantic and upwelling and surface-ocean return flow from the Pacific. From a deep-water perspective, the single southern-sourced ventilation of the Indian Ocean means that its $\mathrm{Nd}$ isotopic composition through time should simply reflect changes in the relative proportions of North Atlantic and Pacific derived waters in the Southern Ocean. From a nutrient-proxy perspective, the Indian Ocean is a cul de sac; i.e. the deep Indian Ocean is only ventilated from the south, so the nutrient content of northward-flowing deep waters is not modified by mixing with any other deep-water mass. Instead, the deep-water nutrients progressively accumulate, as with aging. This potentially allows for large-scale decoupling of a quasi-conservative proxy from a nutrient-dependant proxy in the Indian Ocean, especially during periods of high productivity and/or sluggish deep-ocean circulation.

The Indian Ocean is ventilated at depth along three flow paths: the Deep Western Boundary Current (DWBC); and the middle and eastern paths as flows resembling DWBC along the South-East Indian Ridge and along the Ninetyeast Ridge, respectively (Figure 1). The DWBC, which flows along the east coast of Africa, is primarily composed of waters sourced from Lower Circumpolar Deep Water (LCDW), which has a predominant proportion of Antarctic Bottom Water (AABW). The LCDW-derived waters of the deep western boundary current flow below $3.8 \mathrm{~km}$, and pass through the Madagascar and Mascarene basins before entering the Somali Basin via the Amirante Passage. These bottom waters are overlain by Upper Circumpolar Deep Water (UCDW), which has a greater component of NADW with little homogenization by the Southern Ocean. This UCDW normally occupies a depth range of 2.0 to $3.8 \mathrm{~km}$ and also flows northwards along the eastern coast of Africa (McCave et al., 2005; Schott and McCreary, 2001; Thomas et al., 2006). Red Sea and Northern Arabian Sea Intermediate Waters do not penetrate below $1000 \mathrm{~m}$, and lose their identity as they cross the equator by mixing with low-salinity Indonesian Through-flow Waters or by intermediate Sub-Antarcticmode waters. In contrast to the western boundary current, the Indian Ocean's Central Indian 
Basin is ventilated by waters primarily sourced from Upper Circumpolar Deep Water (UCPDW). The eastern basins of the Indian Ocean are ventilated by Circumpolar Deep Water which separates from the Antarctic Circumpolar Current after passing Kerguelen Plateau.

\section{Methods}

Core SK129-CR2 ( $3^{\circ} \mathrm{N}, 76^{\circ} \mathrm{E}, 3800 \mathrm{~m}$ b.s.l.) is located at the terminus of the middle arm of the Indian Ocean ventilation. This location is upstream of the Indian Peninsular, making local continental inputs negligible, and at a depth placing it at the bottom of UCPDW, allowing comparison with Atlantic records. Samples of approximately $3 \mathrm{~cm}^{3}$ were used for measurement of continuous downcore $\mathrm{Nd}$ isotopes and benthic foraminiferal stable isotopes. Planktonic foraminiferal trace metal and stable isotope records were measured on separate subsections of the same sediment core, while samples for radiocarbon dating were also taken from the Holocene through MIS 3 sections.

The stable isotopes were measured at The Godwin Laboratory for Palaeoclimate Research, Department of Earth Sciences, University of Cambridge. Epifaunal benthic foraminifera Cibicidoides wuellerstorfi $\delta^{13} \mathrm{C}$ and $\delta^{18} \mathrm{O}$ records are reported in this paper (Table 1). Foraminifera were transferred into sample vials, crushed and soaked in a solution of $3 \%$ hydrogen peroxide for 30 minutes before being removed. Acetone (analytical reagent grade) was added and the sample ultrasonicated for $30 \mathrm{~s}$, then the liquid was carefully removed using a tissue. The samples were dried at $50^{\circ} \mathrm{C}$ overnight. The vials were sealed with a septa and screw cap and analyzed using a Micromass Multicarb Sample Preparation System attached to a VG SIRA mass spectrometer or a VG PRISM mass spectrometer. Each run of 30 samples was accompanied by 10 reference carbonates and 2 control samples. The results are reported with reference to the international standard PeeDee Belemnite (VPDB) and the precision is better than $\pm 0.06 \%$ for ${ }^{12} \mathrm{C} /{ }^{13} \mathrm{C}$ and $\pm 0.08 \%$ for ${ }^{16} \mathrm{O} /{ }^{18} \mathrm{O}$. The infaunal benthic foraminifera Uvigerina

peregrina $\delta^{13} \mathrm{C}$ and $\delta^{18} \mathrm{O}$ data shown in this paper have been previously published (Banakar, 2005), but were also analyzed at the Godwin Laboratory in Cambridge using the same methods.

For $\mathrm{Mg} / \mathrm{Ca}$ measurements we used Globigerinoides sacculifer (without the terminal sac), picked from the same size-interval $(250-350 \mu \mathrm{m})$ fraction extracted from the same interval sub- 
sections of the sediment core as those used for the oxygen-isotope measurements. G. sacculifer is a dissolution-resistant mixed-layer foraminifera that lives at a depth of $\sim 20 \mathrm{~m}$ ((Dekens et al., 2001)) and exhibits nearly uniform distribution of Mg between various chambers, suggesting minimal habitat migration ((Eggins et al., 2003)). However, a terminal-sac-like chamber forms in deeper water during gametogenesis, and it is necessary to avoid specimens with this chamber for studies related to mixed-layer processes. Around $60 \mathrm{G}$. sacculifer tests were crushed under a binocular microscope with a drop of water. Visible clay lumps, oxide particles, and mineral grains were removed using a fine brush. After this preliminary cleaning the calcite fragments were subjected to chemical cleaning, organic removal, and Mg-polishing steps following the procedures described by (Elderfield and Ganssen, 2000). The measurement of $\mathrm{Mg} / \mathrm{Ca}$ ( $\mathrm{mmol} / \mathrm{mol}$ ) on a Varian ${ }^{\circledR}$ simultaneous ICP-AES, after adjusting the concentration of Ca to 65 p.p.m. The quality-control solution was run after every five samples. Aluminium, manganese, and iron were monitored to ensure contamination-free data. The calcite $\mathrm{Mg} / \mathrm{Ca}$ was translated into temperature using the calibration of (Dekens et al., 2001) derived for the equatorial Pacific using G. sacculifer. The core-top section has yielded an $\mathrm{Mg} / \mathrm{Ca}$-derived thermocline temperature of $22.6^{\circ} \mathrm{C}$ (Table 2), which matches the modern annual thermocline temperature in the region.

The age model was established by selecting 11 depths for planktonic foraminiferal radiocarbon dates, from the Holocene, deglacial, and glacial sections of the sediment core. Radiocarbon was measured on G. ruber and G. sacculifer (without the terminal sac) at the Scottish Universities Environmental Research Centre (SUERC). Samples were corrected assuming a reservoir age of 350 yr ((Butzin et al., 2005; Cao et al., 2007) and http://radiocarbon.LDEO.columbia.edu) and were converted to calendar years using the Fairbanks calibration curve 01.07 (Fairbanks et al., 2005). The age model is reported in (Table 3). The stratigraphy beyond the radiocarbon-dating window was established by tuning the benthic foraminifera (C. wuellerstorfi) $\delta^{18} \mathrm{O}$ shifts at the MIS 6-5e and MIS $5 \mathrm{a}-4$ boundaries in SPECMAP (Martinson et al., 1987). The extinction of G. ruber (pink variety) in the Indian Ocean (Thompson et al., 1979) at $125 \mathrm{kyr}$ was used as an independent tie-point. This age model yields sedimentation rates ranging from 1.7 to $3.5 \mathrm{~cm} / \mathrm{kyr}$.

Neodymium isotopes were measured on acidic-reductive leaches of authigenic sedimentary Fe-Mn oxyhydroxides, following a similar procedure to that described by (Bayon et 
al., 2003; Bayon et al., 2002a; Gutjahr et al., 2007; Rutberg et al., 2000), which is based on (Chester and Hughes, 1967). In brief, the bulk sediment samples were leached with a sodium acetate buffered acetic-acid solution to remove carbonate. After three washes with de-ionized water, the carbonate-free fraction was allowed to react for one hour in $0.02 \mathrm{M}$ hydroxylamine hydrochloride in $25 \%$ (v/v) acetic acid, which reduces and removes the Fe-Mn oxides coating the detrital sediment. This leachate was centrifuged at high speeds and decanted thrice in sequence to prevent transfer of detrital particles. After drying the leachate, and conversion to a nitrate form, the rare earth element (REE) fraction was separated from the Fe-Mn leachates using Eichrom TRUspec ${ }^{\mathrm{TM}}$ resin. Neodymium was then separated from the REE fraction using Eichrom LNSpec ${ }^{\mathrm{TM}}$ resin, on volumetrically calibrated columns. The $\mathrm{Nd}$ isotopic composition was analyzed using a Nu Plasma HR multi-collector plasma mass spectrometer (MC-ICPMS) at the University of Cambridge, fitted with an Edwards high-capacity rotary pump for the expansion chamber and Nu DSN100 desolvating nebulizer (Table 4). The mass-fractionation correction was made by monitoring ${ }^{146} \mathrm{Nd} /{ }^{144} \mathrm{Nd}$ and applying an exponential-fractionation correction. Samples were analyzed during nine sessions, and each sample was bracketed with analyses of the JNdi-1 neodymium isotopic standard (Tanaka et al., 2000). The samples were standard corrected to a value of $0.512118 \pm 7$ for the JNdi-1 neodymium isotopic standard, which is based on our own in-laboratory cross calibration between JNdi-1 and La Jolla, which is within error of the value of $0.512115 \pm 7$ reported by (Tanaka et al., 2000). During the course of this

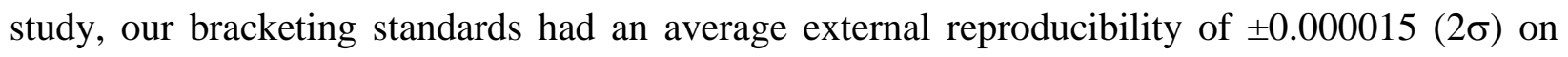
${ }^{143} \mathrm{Nd} /{ }^{144} \mathrm{Nd}$, which corresponds to an average $\pm 0.25(2 \sigma) \varepsilon_{\mathrm{Nd}}$ error.

\section{Results}

The benthic foraminiferal C isotope record from SK129-CR2 shows a number of major changes during the last $150 \mathrm{kyr}$. During deglacial terminations I and II, which are clearly denoted by large benthic foraminiferal $\delta^{18} \mathrm{O}$ shifts: large positive shifts in benthic $\delta^{13} \mathrm{C}$ are also observed (Figure 2). However, the benthic $\delta^{13} \mathrm{C}$ record does not simply oscillate between glacial and interglacial values. For example, MIS 6 has a $\delta^{13} \mathrm{C}$ value of $-0.4 \%$ while MIS 2 (LGM) has a $\delta^{13} \mathrm{C}$ value of $0.15 \%$ o to $-0.2 \%$. Likewise, the peak of the MIS 5e interglacial, that is considered equivalent to the Holocene, has lower $\delta^{13} \mathrm{C}$ values (approximately 0.0 to $+0.2 \%$ ) than 
the Holocene and a core-top value of $+0.5 \%$. This change in the $\delta^{13} \mathrm{C}$ appears to occur in the mid- to late MIS 5, and can be interpreted as either a relative increase in the amount of North Atlantic derived waters in the Indian Ocean, or a relative decrease in the deep Indian Ocean nutrient content.

The Nd isotope record preserved by Fe-Mn oxides leached from SK129-CR2 has a Nd isotopic composition identical to modern deep equatorial Indian Ocean bottom waters. The $\varepsilon_{\mathrm{Nd}}$ of the Fe-Mn leachate from the core-top section (at $2.5 \mathrm{~cm}$ depth) of SK129-CR2 (dated to 4.56 kyr calendar BP, matches the nearest $\mathrm{Nd}$ isotope seawater measurement from a Somali Basin profile (from site CD-1507 at 0609.2S, 5053.7E) (Bertram and Elderfield, 1993) (Figure 3). The Nd isotope record shows a pattern which is similar to the benthic $\delta^{13} \mathrm{C}$, but it differs in important ways. Like the $\delta^{13} \mathrm{C}$ record, the $\mathrm{Nd}$ isotope record shows large changes during deglacial terminations I and II, with lower values during interglacials MIS 5 and 1, and higher values during glacials MIS 2, 4, and 6 (Figure 2). A series of changes are observed in the Nd isotope record during MIS 3, a period of rapid climate variability. The similarity between the $\delta^{13} \mathrm{C}$ and Nd isotope records during the MIS 6-5, MIS 5-4, and MIS 2-1 transitions suggests that both proxies are being affected by glacial-interglacial changes in the relative proportion of North Atlantic derived waters in the Indian Ocean. However, in contrast to the $\delta^{13} \mathrm{C}$ record, glacials MIS 6 and 2 have similar Nd isotope values, as do interglacials MIS 5 and 1. In addition, there is a large $\delta^{13} \mathrm{C}$ change during late MIS 5 while the $\mathrm{Nd}$ isotope record changed very little. This is evidence that the Fe-Mn oxides leached from SK129-CR2 are recording past changes in central equatorial Indian Ocean deep waters. It is further supported by the $\mathrm{Nd}$ isotopic composition of the Fe-Mn crust top of SS663 (located at $13^{\circ} \mathrm{S}, 76^{\circ} \mathrm{E}$ ) which has a $\varepsilon_{\mathrm{Nd}}$ of -7.25. Fe-Mn crusts grow slowly and integrate the Nd isotopic composition of interglacials and glacials, making this a reasonable value.

\section{Proxy records of deep Indian Ocean paleocirculation}

Does the Nd isotope record reflect changes in deep-water mass provenance in the Indian Ocean? The Nd isotope record can be interpreted in a number of ways, including changes in the relative proportion of Atlantic-derived deep waters, boundary exchange, or input of $\mathrm{Nd}$ to the 
ocean from rivers and dust. In the latter case, changes in the strength of the Asian monsoon and resulting changes in the Ganges-Brahmaputra outflow and Arabian dust input may have affected the Nd isotope record at SK129-CR2. However, we argue that there are a number of reasons to support the interpretation that this record is reflecting bottom-water circulation changes rather than local inputs forced by regional climate variations.

Firstly, the location of SK129-CR2 places it at the end of the pathway of deep-water flow into the central Indian Ocean. Unlike the western and eastern ventilation pathways, the pathway which ventilates the central Indian Ocean does not come into contact with any major continental boundaries, such as east coast of Africa or western Australia and the Indonesian island arcs. The lack of flow along the eastern boundary of the Indian Ocean may be particularly important because studies have shown the propensity of volcanogenic sediments to exchange $\mathrm{Nd}$ with seawater (Jeandel et al., 1998). The middle ventilation pathway also appears to separate from the Antarctic Circumpolar Current (ACC) before coming into contact with Kerguelen, another potential source of boundary exchange (Jeandel et al., 2008). There are some volcanic islands and seamounts located along the flow path of the waters reaching the SK129-CR2 core site, and the deep-water flow path passes through fracture zones and over a mid-ocean ridge. However, recently measured seawater profiles from the Pacific have a uniformity which suggests that boundary exchange from small seamounts is not enough to significantly change bottomwater Nd isotopic compositions (Amakawa et al., 2006).

Secondly, the Nd isotopic compositions of surface waters appear to be more easily changed by dust input (Bayon et al., 2002b; Tachikawa et al., 1999b) than those of bottom waters (Jones et al., 1994). Models of regional dustiness also suggest greater dust input to the Indian Ocean during the last glacial (Mahowald et al., 2006), which is supported by the higher aluminium content of glacial detrital sediments from Somali margin cores, interpreted as a proxy of dustiness indicating higher dust contact during glacials than interglacials (Ivanochko et al., 2005). The nearest sources of dust to SK129-CR2 are India and Persia, which have a $\varepsilon_{\mathrm{Nd}}$ of -13.5 and -9 , respectively (Sirocko, 1995; Stoll et al., 2007), which is more negative than Indian Ocean seawater. Arabian dust has a $\varepsilon_{\mathrm{Nd}}$ of -6 , however is presently confined to the western Arabian Sea and Somali Basin and records of the isotopic composition of Arabian Sea detrital 
sediments indicate no major glacial-interglacial shifts in dust sourcing (Sirocko, 1995; Stoll et al., 2007). Therefore, in a scenario where dustiness increased during the glacial, and a significant contribution of $\mathrm{Nd}$ was released from dust to seawater, this would cause the SK129-CR2 to be more negative during the glacial. This is opposite of what we observe in our $\mathrm{Fe}-\mathrm{Mn}$ leachate $\mathrm{Nd}$ isotope record, which instead shows more-positive $\mathrm{Nd}$ isotopic compositions during the glacial, and is evidence against changes in dust flux being an important control.

Thirdly, it is not likely that local changes in seawater Nd isotopic composition affected this record. No deep-water formation occurs in the Indian Ocean to transport this riverine signal to a depth of $3800 \mathrm{~m}$ b.s.l. While intermediate water masses do form in the Arabian Sea, they are unlikely to cross the Chagos-Laccadiv-Maladive Ridge. The only limited possibility for them to enter into the central Indian Basin is through a small gap at $\sim 10^{\circ} \mathrm{S}$ between the MidIndian Ridge and the Chagos-Laccadiv-Maladive Ridge. Thus it is highly unlikely that waters formed in the Red Sea or Arabian Sea reached SK129-CR2. Recent studies of planktonic foraminifera cleaned of Fe-Mn oxides (Stoll et al., 2007), and the acid-leachable component of bulk sediments (Gourlan et al., 2008) from the Bengal fan, both interpreted as near-surface water compositions, show Holocene and glacial Nd isotopic compositions which are very similar to those we have measured in the leached Fe-Mn oxides from SK129-CR2. If the records of (Gourlan et al., 2008; Stoll et al., 2007) are being correctly interpreted as recording surface water, this may suggest that surface and deep waters in the equatorial Indian Ocean have no $\mathrm{Nd}$ isotope gradient and that surface and deep waters changed in a similar way at these locations on glacial-interglacial timescales. Although nearby seawater $\mathrm{Nd}$ isotopic compositions are yet to be measured, it seems highly unlikely that local Ganges-Brahmaputra river outflow and global deep-ocean circulation changed in unison to give the same $\mathrm{Nd}$ isotopic composition. Another possible interpretation is that there is particulate transfer of the surface-ocean $\mathrm{Nd}$ signal to the deep ocean. Transport of particles from the Bay of Bengal to the western equatorial Indian Ocean has been previously suggested from even further away than the SK129-CR2 site (Banakar et al., 2003). However, the lack of strong northerly bottom currents in the Bay of Bengal implies very little sediment transport. A detrital sediment deposition rate at the $\mathrm{Fe}-\mathrm{Mn}$ crust SS663 $\left(13^{\circ} \mathrm{S}, 76^{\circ} \mathrm{E}\right)$, which is located about $1500 \mathrm{~km}$ south of SK129-CR2, was calculated to be on the order of $10^{-5} \mathrm{~cm} / \mathrm{kyr}$. Given the $2-3 \mathrm{~cm} / \mathrm{kyr}$ sedimentation rate at SK129-CR2, 
contribution of detritus from the Bengal Fan is unlikely to be significant. In addition, such a signal can only be carried by particles and therefore should be largely decoupled from a deepwater signal such as benthic $\delta^{13} \mathrm{C}$.

Finally, evidence for changes in water-mass provenance and circulation is suggested by the glacial-interglacial changes in the $\mathrm{Nd}$ and $\mathrm{C}$ isotope records. The observed lower $\mathrm{Nd}$ isotope values and more-positive benthic $\mathrm{C}$ isotope values during interglacials are consistent with more Atlantic-derived waters reaching the Indian Ocean during the interglacials. More-positive Nd isotope values and lower benthic $\mathrm{C}$ isotopes during the glacial are consistent with less deep waters of Atlantic derivation reaching the glacial Indian Ocean. The SK129-CR2 Indian Ocean $\varepsilon_{\mathrm{Nd}}$ record is also very similar to the record from the South Atlantic deep Cape Basin (Piotrowski, 2004; Piotrowski et al., 2005; Piotrowski et al., 2008), having the same absolute $\varepsilon_{\mathrm{Nd}}$ values and glacial-interglacial changes which are identical in magnitude and direction (Figure 4). Since the deep water of the South Atlantic is the primary source of deep water in the central Indian Ocean, these similarities are strong evidence for the propagation of a $\mathrm{Nd}$ isotope signal from the South Atlantic to the Indian Ocean without significant alteration along the flow path.

\section{Propagation of NADW between the Atlantic and Indian Oceans}

The Nd and C isotope changes in the equatorial Indian Ocean record are consistent with their being caused by changes in the proportions of water sourced in the North Atlantic reaching the core site. During interglacial stages (MIS 5 and 1), low $\mathrm{Nd}$ and high $\mathrm{C}$ isotope values suggest greater ventilation of the deep equatorial Indian Ocean by northern-sourced waters; while during glacial periods, the higher $\mathrm{Nd}$ and depleted $\mathrm{C}$ isotope values together suggests more nutrient-rich waters with a reduced contribution from the North Atlantic component. A number of smaller fluctuations in $\varepsilon_{\mathrm{Nd}}$ occurred during MIS 3. The $\mathrm{Nd}$ isotope record may suggest more Nd derived from the North Atlantic reaching the Indian Ocean during three periods within MIS 3, which may correspond to major interstadial-stadial variations (Figure 4). However, it is interesting to note that while the SK129-CR2 record appears to preserve evidence of MIS 3 variability, it does not show evidence of rapid fluctuations (Bolling-Allerod-Younger Dryas) during the last deglaciation. This may be due to changes in sedimentation rate, or perhaps an internal mixing threshold for the ability of the ocean to transmit rapid chemical changes over 
long path lengths. Equatorial Indian Ocean records at intermediate depth (Naqvi et al., 1994; Waelbroeck et al., 2006), also show reduced NADW export to the Indian Ocean during cold periods, such as Heinrich Ice-rafting Event 1 (H1) and the Younger Dryas. Although the deeper SK129-CR2 record does not have sufficient resolution to examine the H1 and Younger Dryas periods specificially, the similar response during cold periods suggests a link between interbasinal (Atlantic to Indian) transfer of waters. It may suggest that during cold periods the deep and intermediate circulation in the Indian Ocean changed together, or that deep waters with a North Atlantic signal were upwelled in the equatorial Indian Ocean to intermediate depths.

On glacial-interglacial timescales the $\mathrm{Nd}$ isotope record in the equatorial Indian Ocean varies between -6.5 and -9.5 , which is identical to the deep Cape Basin record from the South Atlantic (Piotrowski, 2004; Piotrowski et al., 2005; Piotrowski et al., 2008). The lack of a Nd isotope gradient between these two sites may be partially due to the fact that the two sediment cores are at different depths. The deep Cape Basin sites (RC11-83/TNO57-21) are located at approximately $4800 \mathrm{~m}$ b.s.l., which is within the zone of mixing between south-flowing NADW and north-flowing AABW, and has a large proportion of southern-sourced water. (Piotrowski et al., 2008) have shown that sites at water depths of 2 to $3 \mathrm{~km}$ in the South Atlantic have morenegative core-top $\varepsilon_{\mathrm{Nd}}(-10.1$ to -12.2$)$, reflecting a greater proportion of NADW relative to AABW. This predominantly northern-sourced water with a $\varepsilon_{\mathrm{Nd}}$ of -10.1 to -12.2 flows southwards into the Southern Ocean before propagating into the Indian Ocean and eventually reaching SK129-CR2 at $3800 \mathrm{~m}$ b.s.l.. This difference in the $\varepsilon_{\mathrm{Nd}}$ between the Holocene South Atlantic and equatorial Indian Ocean corresponds to a $\varepsilon_{\mathrm{Nd}}$ gradient of 0.6-2.5 epsilon units. Further, (Piotrowski et al., 2008) have also shown that, during the glacial, the South Atlantic sediment core sites recorded more-positive $\varepsilon_{\mathrm{Nd}}(-6)$ than during the Holocene (-9.5). Comparing this to the glacial $\varepsilon_{\mathrm{Nd}}$ of -6.5 in the equatorial Indian Ocean sediment core site, suggests that during the glacials AABW alone ventilated both the South Atlantic and Indian Oceans.

The observed glacial-interglacial shifts in both records suggest that during glacial-interglacial transitions the changes in the flux of NADW modulated the $\varepsilon_{\mathrm{Nd}}$ of the Southern Ocean, which was then effectively propagated to the Indian Ocean. During MIS 3, between 30 and $60 \mathrm{kyr} \mathrm{BP}$, a series of variations can be observed in both the records. The 
chronology of this section of the core is not well constrained, and assumes a linear sedimentation rate from the radiocarbon date at 34.6 kyr calendar BP to the MIS 5-4 boundary, which is not likely to have been the case. Given the ambiguities of the MIS 3 chronology, it is difficult to argue whether the Nd isotope records in the Indian Ocean and South Atlantic Ocean are in-phase or anti-phased during MIS 3. The magnitude of the MIS 3 shifts appears to be marginally attenuated in the Indian Ocean record, indicating a possible suppression of the NADW signal by a southern-sourced water mass with higher $\varepsilon_{\mathrm{Nd}}$. The similarity between the $\mathrm{Nd}$ isotope records of the equatorial Indian Ocean and South Atlantic on glacial-interglacial timescales may be taken as further evidence that the $\mathrm{Nd}$ isotopes respond primarily to changes in water-mass provenance over long path lengths in the deep ocean rather than local-scale additions of $\mathrm{Nd}$ or sedimentary input.

\section{Evidence for high tropical Indian Ocean productivity during the last interglacial}

The equatorial Indian Ocean $\varepsilon_{\mathrm{Nd}}$ and benthic $\delta^{13} \mathrm{C}$ records show that the nutrient content of deep waters has been decoupled from deep-circulation changes during some parts of the last glacial-interglacial cycle (MIS 6 through MIS 5). The benthic $\delta^{13} \mathrm{C}$ record shows glacial-interglacial changes during the last $150 \mathrm{kyr}$. Though the glacial-interglacial $\delta^{13} \mathrm{C}$ changes (MIS 6-5e, MIS 5a-4, and MIS 2-1) are all similar in magnitude, they appear to be superimposed on a long-scale trend towards higher values during the last 150 kyr (Figure 2). The benthic $\delta^{13} \mathrm{C}$ changes from average values of $-0.4 \%$ during MIS 6 to $+0.1 \%$ o during MIS 5c-e (Termination II) are similar in magnitude but distinctly lower in absolute values than the similar change during the deglacial transition, which is from $-0.2 \%$ during the LGM to $+0.5 \%$ during the Holocene (Termination I). Comparison of the benthic $\delta^{13} \mathrm{C}$ values during the last full glacial (MIS 2), MIS 4, and the penultimate glaciation (MIS 6), as well as comparison between the Holocene (MIS 1) and the last interglacial (MIS 5) show that the more recent interglacial and glacial periods have higher benthic $\delta^{13} \mathrm{C}$ than their predecessors. In contrast, the $\mathrm{Nd}$ isotopes show no such trend. During both full glacials (MIS 6 and MIS 2) and interglacials (MIS 5 and the Holocene) the $\mathrm{Nd}$ isotopic compositions are very similar, $\varepsilon_{\mathrm{Nd}}=-6.5$, and $\varepsilon_{\mathrm{Nd}}=-9$, respectively. The relationship between the $\mathrm{Nd}$ and $\mathrm{C}$ isotope records appears to have changed some time within MIS 5, although whether this was gradual or abrupt is difficult to ascertain. 
If the $\varepsilon_{\mathrm{Nd}}$ record is interpreted as reflecting changes in the propagation of NADW into the Indian Ocean, then the benthic $\delta^{13} \mathrm{C}$ record must have a secondary control other than water-mass sourcing. If $\mathrm{Nd}$ isotopes from $\mathrm{Fe}-\mathrm{Mn}$ leachates are controlled by changes in deep-water sourcing, then the decoupling from benthic $\delta^{13} \mathrm{C}$ could suggest either slower flow speeds, higher Indian Ocean nutrient regeneration, or lower mean ocean $\delta^{13} \mathrm{C}$, during early MIS 5 and late MIS 6 ( 90 to $100 \mathrm{kyr}$ ) compared to the last glacial and the Holocene. Time-series of the sortable-silt recorded by the WIND28K sediment core, a southern site in the Indian Ocean, does not indicate weakened inflow of southern-sourced waters to the Indian Ocean during the Holocene and MIS 5 (McCave et al., 2005), a finding confirmed using ${ }^{231} \mathrm{~Pa} /{ }^{230} \mathrm{Th}$ ratios (Thomas et al., 2007). We will therefore examine evidence for changes in Indian Ocean productivity, as well as comparing Indian and Pacific Ocean (mean ocean) nutrient contents.

The hypothesis of higher productivity during MIS 5 is supported by comparing C isotopes in epifaunal and infaunal benthic foraminifera (Figure 5). Infaunal foraminifera live within porewaters, which tend to have lighter $\mathrm{C}$ isotopic compositions than bottom waters, due to oxidation of organic matter in the sediment (Mackensen and Douglas, 1989; Mackensen et al., 1993; Mackensen et al., 2000). The C isotopic composition of infaunal species $U$. peregrina measured on this site shows glacial-interglacial variations with a step change through MIS 5e-d (Banakar, 2005). When compared to the epifaunal C. wuellerstorfi data, we observe an increased epifaunal-infaunal $\delta^{13} \mathrm{C}$ difference during the early to mid-MIS 5 (120 to $100 \mathrm{kyr}$ ), the same period as when $\mathrm{C}$ and $\mathrm{Nd}$ isotopes show a decoulping between water-mass provenance and nutrient content. This is indicative of a stronger gradient between the $\mathrm{C}$ isotopic composition of porewaters and bottom waters, likely produced by an increase in the degradation of organic matter in sediments. Additional support for regional productivity changes comes from the $\mathrm{Mg} / \mathrm{Ca}$ of thermocline-dwelling planktonic foraminifera Neogloboquadrina dutertrei (Figure 6), which shows cooling (shoaling) of the equatorial Indian Ocean thermocline during the mid-MIS 5. This suggests a possible link to surface-ocean circulation, and may indicate a shift to increased upwelling and higher primary productivity during the last interglacial.

A wider view of paleoceanographic data also supports a regional, or even global, change in productivity. Stacked benthic $\delta^{13} \mathrm{C}$ records can be used to reconstruct gradients between sites 
caused by regeneration of organic carbon in deep waters in regions of limited mixing between water masses, such as the Indian and Pacific Oceans. We specifically look at whether large benthic $\delta^{13} \mathrm{C}$ gradients existed along the deep-water advection pathways during MIS 5, which may suggest increased addition of nutrients to deep waters or slower water-mass flow speeds. For example (Hall et al., 2001) coupled this approach with the sortable-silt proxy to reconstruct flow-speed changes in the Pacific Ocean. This type of analysis has not yet been attempted in the deep Indian Ocean, due to the lack of high-resolution $\delta^{13} \mathrm{C}$ records. However the equatorial Indian $\delta^{13} \mathrm{C}$ record from SK129-CR2 (this study) can be compared to a high-resolution $\delta^{13} \mathrm{C}$ record from the southwestern Indian Ocean (WIND28K) (McCave et al., 2005). These two sites are not technically on the same deep-water flow path, because WIND28K is situated along the deep western Indian Ocean boundary current while SK129-CR2 is ventilated by deep waters entering the central Indian Ocean. However, the latitudinal gradient in modern Indian Ocean $\delta^{13} \mathrm{C}$ (Kroopnick, 1985) exhibits a distinct latitudinal change with little longitudinal variation, suggesting that comparing the two sites is useful for a broad reconstruction of the patterns of nutrient addition to deep water during its transit from south to north.

Comparison of the WIND28K (southern Indian Ocean site) and SK129-CR2 (equatorial Indian Ocean site) benthic $\delta^{13} \mathrm{C}$ records (Figure 7) shows that the equatorial site is lower than the southern site by 0.05 to $0.15 \%$ o throughout the last glacial cycle,. The lower benthic $\delta^{13} \mathrm{C}$ values at the equatorial site are expected because nutrients progressively accumulate in the Indian Ocean during northward bottom-water flow. Such consistency in the modern $\delta^{13} \mathrm{C}$ gradient, and the existence of this gradient during the last glacial clearly indicate that the Indian Ocean has been ventilated by southern sources during the last $130 \mathrm{kyr}$. During MIS 5 , the $\delta^{13} \mathrm{C}$ gradient between the southern (WIND28K) and equatorial (SK129-CR2) Indian Ocean sites reached a maximum of 0.3 to $0.4 \%$, likely indicating higher nutrient regeneration along the flow path. More sluggish deep-water flow speeds in the western Indian Ocean can be discounted because the sortable-silt and ${ }^{231} \mathrm{~Pa} /{ }^{230} \mathrm{Th}$ ratio records from WIND28K do not indicate weakened inflow of southern-sourced waters to the Indian Ocean during this time period. Additionally, though the $\mathrm{Nd}$ isotope record is controlled by the water-mass provenance, rather than changes in strength of the circulation, the similarity between the $\varepsilon_{\mathrm{Nd}}$ values of MIS 5 and the Holocene ( -9.5), as reflected in the equatorial Indian Ocean record (Figure 2), suggests a similar deep- 
circulation regime during the present as well as last interglacial period. Higher productivity is thus a likely scenario to explain the enhanced latitudinal benthic $\delta^{13} \mathrm{C}$ gradient during early MIS 5, and perhaps MIS 6.

The equatorial and southwestern Indian Ocean $\delta^{13} \mathrm{C}$ records (SK129-CR2 and WIND28K, respectively), representing the Indian Ocean arm of the global thermohaline circulation, are compared to Pacific Ocean $\delta^{13} \mathrm{C}$ records from ODP Site 1123 (Chatham Rise, SW Pacific; (Hall et al., 2001) and ODP Site 849 (equatorial Pacific) (Mix and al, 1995) representing the Pacific arm of the global thermohaline circulation (Figure 7). During the warm periods $(0-15,30-50$, and $80-130 \mathrm{kyr})$, the $\delta^{13} \mathrm{C}$ of the sites at the start of the inflow from the Southern Ocean into the Indian and Pacific Oceans (WIND28K and ODP Site 1123, respectively), show consistently higher values than at the equatorial sites (SK129-CR2 and ODP Site 849) in both basins. This is likely because a greater proportion of NADW entered the Southern Ocean during the warmer periods. The $\delta^{13} \mathrm{C}$ of SK129-CR2 and ODP Site 849, both equatorial sites at the termination of two independent circulation and nutrient-regeneration pathways, also show comparable changes through time. The $\delta^{13} \mathrm{C}$ in equatorial Pacific Ocean sediment cores, including ODP Site 849, have been interpreted as reflecting changes in the mean ocean $\delta^{13} \mathrm{C}$ (Boyle, 1992; Curry, 1988; Duplessy et al., 1988). Based on the fact that SK129-CR2 tracks $\delta^{13} \mathrm{C}$ changes in ODP Site 849, we suggest that the deep equatorial Indian Ocean has undergone evolution in its deep-water $\delta^{13} \mathrm{C}$ that is similar to large parts of the deep Pacific. Further, considering the absence of any communication pathway between the deep Pacific and deep Indian Ocean, and the observation that the deep central Pacific Ocean maintained a very different $\varepsilon_{\mathrm{Nd}}$, of -4 , during the last glacial and the Holocene (Marchitto et al., 2005), which is distinct from the Indian Ocean record, rules out any possibility of deep IndoPacific water-mass exchange. As the equatorial Indian Ocean sediment core (SK129-CR2) recorded "mean ocean" $\delta^{13} \mathrm{C}$ characteristic of the deep equatorial Pacific this suggests similar aging of the deep waters in both basins. The gradient between ODP Site 1123 (Chatham Rise, southwestern Pacific) $\delta^{13} \mathrm{C}$ and ODP Site 849 (equatorial Pacific) is also similar to the gradient between WIND28K (southwestern Indian Ocean) and SK129-CR2 (equatorial Indian Ocean). Because the rapidity of circulation in the Southern Ocean ensures it has a uniform $\delta^{13} \mathrm{C}$, this 
suggests a similar amount of carbon addition to the deep waters en-route to their respective equatorial termination points through nutrient regeneration.

The increased benthic $\delta^{13} \mathrm{C}$ gradient during MIS 5 along these two pathways may suggest higher nutrient regeneration during the last interglacial. This suggests a common link in the delivery of organic carbon to the deep ocean between these two regions, which was enhanced during the last interglacial. One possibility is that primary productivity and biological-pump efficiency in the Indo-Pacific region was enhanced. The Southern Oscillation controls the strength of the equatorial westerlies in the Indian Ocean, and also plays a role in controlling El Nino Southern Oscillation condition in the Pacific via the Walker circulation. In a study of faunal assemblage in core MD900963 (located off the Maldives in the vicinity of SK129-CR2) (Beaufort et al., 1997) observed a period of enhanced primary productivity from 120 to 80 kyr. They also predicted that Southern-Oscillation-forced changes in primary productivity should cause a correlation in primary productivity between the Maldives (western equatorial Indian Ocean) and the eastern equatorial Pacific. This is consistent with the benthic $\delta^{13} \mathrm{C}$ records being similar between the equatorial Indian and Pacific Oceans and the similar benthic $\delta^{13} \mathrm{C}$ gradients between the southern and equatorial Indian and Pacific Oceans, as observed in this study.

\section{Conclusions}

Utilizing multiple proxies such as foraminiferal stable isotopes $\left(\delta^{13} \mathrm{C}\right.$ and $\left.\delta^{18} \mathrm{O}\right)$ and radiogenic $\mathrm{Nd}$ isotopes on $\mathrm{Fe}-\mathrm{Mn}$ leachates in dispersed $\mathrm{Fe}-\mathrm{Mn}$ oxide, extracted from an equatorial Indian Ocean sediment core, we have examined past changes in deep-water circulation and nutrient storage along the Indian Ocean arm of the global thermohaline circulation. The Nd isotope record obtained in the present study is very similar to the RC11-83/TNO57-21 Nd isotope record from deep Atlantic Cape Basin (Piotrowski et al., 2004; Piotrowski et al., 2005), indicating an effective propagation of NADW into the Indian Ocean via the Southern Ocean during glacial-interglacial changes, and possibly during MIS 3 variability. Using two deepocean circulation proxies together we demonstrate that the deep-ocean $\delta^{13} \mathrm{C}$ changes can only be partially explained by changes in deep circulation, as indicated by the $\mathrm{Nd}$ isotopes. In particular, the benthic $\delta^{13} \mathrm{C}$ record requires higher amounts of nutrient transfer and storage in the deep Indian Ocean during the last interglacial period (MIS 5). Comparing these records to organic 
carbon contents, epifaunal-infaunal C isotope gradients, and inter-basinal benthic C isotope gradients, points towards locally and regionally increased nutrient regeneration forced by enhanced primary productivity during the last interglacial. A comparison of our record to previously published Indian and Pacific Ocean benthic $\delta^{13} \mathrm{C}$ records suggests a possible globalscale climate link to the Southern Oscillation. This illustrates that physical deep-ocean circulation and climate-forced deep-ocean nutrient storage have changed independently of each other in the past, with observable affects on paleoceanographic proxies.

\section{Acknowledgements:}

Anjali Chodankar and Linda Booth are thanked for assisting in sediment processing and picking foraminifera. We thank Mike Hall for stable-isotope measurements, Mervyn Greaves for assisting in $\mathrm{Mg} / \mathrm{Ca}$ measurements, and Luke Skinner and Stewart Fallon for one radiocarbon analysis. We thank Jo Clegg for proof-reading the manuscript. VKB wishes to thank the St. John's College Council for electing him for visiting fellowship and Nick McCave for nominating during which the $\mathrm{Mg} / \mathrm{Ca}$ work was carried out. This work was supported by NERC grant NE/D002206/1 "Assessing the role of ocean circulation in rapid climate change through the novel integration of high resolution proxy records" to H. Elderfield, and SUERC Radiocarbon grant 1198.1006 to A.M. Piotrowski. 
Table 1 - Benthic foraminiferal $\delta^{18} \mathrm{O}$ and $\delta^{13} \mathrm{C}$ (C. wuellerstorfi)

$\begin{array}{rrr}\begin{array}{r}\text { Age } \\ \text { (kyr) }\end{array} & \text { S }^{18} \mathbf{O} & \boldsymbol{\delta}^{13} \mathbf{C} \\ 3.40 & 2.88 & 0.53 \\ 6.15 & 2.55 & 0.47 \\ 8.48 & 2.72 & 0.44 \\ 9.64 & 3.31 & -0.06 \\ 10.80 & 3.41 & 0.23 \\ 10.35 & 3.41 & 0.23 \\ 12.19 & 3.84 & 0.12 \\ 13.11 & 4.01 & 0.00 \\ 14.04 & 4.16 & 0.00 \\ 15.60 & 4.14 & 0.03 \\ 16.23 & 4.04 & -0.07 \\ 17.48 & 4.53 & -0.09 \\ 18.00 & 4.15 & -0.24 \\ 18.51 & 4.16 & -0.18 \\ 18.51 & 4.16 & -0.18 \\ 20.09 & 4.22 & -0.10 \\ 21.66 & 4.13 & -0.14 \\ 22.65 & 4.13 & -0.14 \\ 25.14 & 4.20 & -0.11 \\ 25.39 & 4.12 & -0.15 \\ 26.70 & 3.96 & -0.06 \\ 27.02 & 4.10 & -0.09 \\ 27.50 & 4.01 & -0.21 \\ 28.99 & 4.22 & -0.08 \\ 29.93 & 4.24 & -0.01 \\ 30.87 & 3.62 & 0.10 \\ 31.81 & 3.79 & -0.10 \\ 32.74 & 3.77 & 0.11 \\ 33.68 & 3.88 & 0.04 \\ 34.62 & 3.76 & 0.05 \\ 35.69 & 3.78 & 0.13 \\ 36.76 & 3.77 & 0.04 \\ 37.83 & 3.81 & 0.02 \\ 38.91 & 3.93 & 0.04 \\ 39.98 & 3.90 & 0.05 \\ 41.05 & 3.81 & 0.08 \\ 42.12 & 3.93 & 0.15 \\ 43.19 & 3.84 & 0.13 \\ 44.27 & 3.89 & -0.12 \\ 45.33 & 3.53 & 0.20 \\ 46.41 & 3.65 & 0.07 \\ 47.48 & 3.69 & 0.03 \\ 48.56 & 3.67 & 0.06 \\ 49.63 & 3.59 & -0.05 \\ 50.70 & 3.68 & 0.09 \\ 51.77 & 3.76 & 0.02 \\ 52.84 & 3.73 & 0.01\end{array}$




$\begin{array}{rrr}53.91 & 3.66 & -0.08 \\ 54.99 & 3.80 & 0.13 \\ 56.06 & 3.60 & 0.02 \\ 57.13 & 3.63 & -0.02 \\ 59.28 & 3.59 & -0.10 \\ 63.56 & 3.71 & -0.21 \\ 67.86 & 3.94 & -0.16 \\ 68.93 & 4.09 & 0.04 \\ 70.00 & 4.36 & -0.05 \\ 70.85 & 3.98 & -0.17 \\ 71.69 & 4.18 & -0.05 \\ 72.54 & 3.77 & -0.10 \\ 73.38 & 3.87 & -0.01 \\ 74.23 & 3.85 & 0.02 \\ 75.08 & 3.57 & 0.11 \\ 76.77 & 3.38 & 0.13 \\ 77.62 & 4.07 & 0.44 \\ 78.46 & 3.53 & 0.23 \\ 79.31 & 3.28 & 0.09 \\ 80.15 & 3.21 & 0.18 \\ 81.00 & 3.21 & 0.19 \\ 82.09 & 3.41 & 0.32 \\ 83.19 & 3.32 & 0.41 \\ 89.74 & 3.42 & 0.07 \\ 94.12 & 3.12 & 0.13 \\ 102.86 & 3.15 & 0.11 \\ 105.05 & 3.31 & 0.07 \\ 107.23 & 3.29 & 0.07 \\ 109.42 & 3.45 & 0.03 \\ 110.51 & 3.33 & 0.03 \\ 112.69 & 2.85 & -0.08 \\ 114.88 & 3.08 & -0.12 \\ 117.07 & 3.18 & 0.06 \\ 119.25 & 2.88 & -0.04 \\ 120.35 & 2.71 & 0.13 \\ 121.44 & 2.88 & 0.00 \\ 123.63 & 3.34 & 0.19 \\ 124.72 & 2.70 & 0.07 \\ 125.81 & 2.86 & 0.20 \\ 126.91 & 2.21 & -0.21 \\ 128.00 & 3.44 & 0.03 \\ 128.94 & 2.44 & -0.18 \\ 129.88 & 3.89 & -0.32 \\ 130.82 & 4.21 & -0.31 \\ 131.76 & 4.01 & -0.24 \\ 132.69 & 4.18 & -0.39 \\ 134.57 & 4.13 & -0.32 \\ 136.45 & 4.40 & -0.46 \\ 138.33 & 4.27 & -0.37 \\ 140.21 & 4.14 & -0.42\end{array}$




$\begin{array}{lll}142.08 & 4.30 & -0.40 \\ 143.96 & 4.19 & -0.39 \\ 145.84 & 4.11 & -0.31 \\ 147.71 & 4.15 & -0.41 \\ 148.65 & 4.17 & -0.40 \\ 153.35 & 4.33 & -0.16\end{array}$

\section{Table 1 caption}

Epifaunal benthic foraminifera Cibicidoides wuellerstorfi $\delta^{13} \mathrm{C}$ and $\delta^{18} \mathrm{O}$ records measured at The Godwin Laboratory for Palaeoclimate Research, Department of Earth Sciences, University of Cambridge. Chronology is based on radiocarbon dates (Table 3) during the last $30 \mathrm{kyr}$, and $\delta^{18} \mathrm{O}$ stratigraphy using the MIS 5-4 and MIS 6-5 boundaries. The results are reported with reference to the international standard PeeDee Belemnite (VPDB) and the precision is better than $\pm 0.06 \%$ o for ${ }^{12} \mathrm{C} /{ }^{13} \mathrm{C}$ and $\pm 0.08 \%$ for ${ }^{16} \mathrm{O} /{ }^{18} \mathrm{O}$. 
Table 2 - Trace metals on planktonic foraminifera ( $N$. dutertrie)

\begin{tabular}{|c|c|c|c|c|}
\hline $\begin{array}{l}\text { Depth } \\
(\mathrm{cm})\end{array}$ & Age (kyr) & $\begin{array}{c}\mathrm{Mg} / \mathrm{Ca} \\
(\mathrm{mmol} / \mathrm{mol})\end{array}$ & $\begin{array}{l}\text { Thermocline } \\
\text { Temperature }{ }^{\circ} \mathrm{C}\end{array}$ & $\delta^{18} \mathrm{O}$ \\
\hline & 4.56 & 1.59 & 22.6 & -1.08 \\
\hline & 6.15 & 1.62 & 22.7 & -0.66 \\
\hline & 7.31 & 1.87 & 23.7 & -1.24 \\
\hline & 9.64 & 1.65 & 22.9 & -0.86 \\
\hline & 11.38 & 1.85 & 23.6 & -0.85 \\
\hline & 13.11 & 1.58 & 22.6 & -0.59 \\
\hline & 14.50 & 1.73 & 23.2 & 0.03 \\
\hline & 16.23 & 1.51 & 22.3 & 0.52 \\
\hline & 17.48 & 1.57 & 22.6 & 0.72 \\
\hline & 18.00 & 1.59 & 22.6 & 0.66 \\
\hline & 18.51 & 1.31 & 21.5 & 0.84 \\
\hline & 20.09 & 1.82 & 23.5 & 0.61 \\
\hline & 21.66 & 1.63 & 22.8 & 0.60 \\
\hline & 25.14 & 1.37 & 21.7 & 0.32 \\
\hline & 26.70 & 1.41 & 21.9 & 0.47 \\
\hline & 27.33 & 1.46 & 22.1 & 0.40 \\
\hline & 29.93 & 1.51 & 22.3 & 0.14 \\
\hline & 31.81 & 1.24 & 21.2 & 0.25 \\
\hline & 33.68 & 1.39 & 21.8 & 0.07 \\
\hline & 35.69 & 1.46 & 22.1 & 0.09 \\
\hline & 37.83 & 1.46 & 22.1 & 0.09 \\
\hline & 39.98 & 1.37 & 21.7 & 0.08 \\
\hline & 42.12 & 1.41 & 21.9 & 0.01 \\
\hline & 44.27 & 1.73 & 23.2 & -0.06 \\
\hline & 46.41 & 1.55 & 22.5 & -0.19 \\
\hline & 48.56 & 1.56 & 22.5 & -0.12 \\
\hline & 50.70 & 1.35 & 21.6 & -0.19 \\
\hline & 52.84 & 1.64 & 22.8 & -0.18 \\
\hline & 54.99 & 1.49 & 22.2 & -0.40 \\
\hline & 57.13 & 1.57 & 22.6 & -0.37 \\
\hline & 59.28 & 1.25 & 21.2 & -0.01 \\
\hline & 61.42 & 1.35 & 21.6 & -0.15 \\
\hline & 63.57 & 1.42 & 21.9 & -0.12 \\
\hline & 65.71 & 1.41 & 21.9 & 0.05 \\
\hline & 67.86 & 1.38 & 21.8 & 0.17 \\
\hline & 70.00 & 1.36 & 21.7 & 0.21 \\
\hline & 71.69 & 1.47 & 22.1 & 0.16 \\
\hline & 73.38 & 1.42 & 21.9 & 0.01 \\
\hline & 75.08 & 1.84 & 23.6 & -0.48 \\
\hline & 76.77 & 1.32 & 21.5 & -0.35 \\
\hline & 78.46 & 1.39 & 21.8 & -0.53 \\
\hline & 80.15 & 1.34 & 21.6 & -0.48 \\
\hline & 82.09 & 1.38 & 21.8 & -0.43 \\
\hline & 84.28 & 1.77 & 23.3 & -0.71 \\
\hline & 86.47 & 1.57 & 22.6 & -0.50 \\
\hline & 88.65 & 1.27 & 21.3 & -0.30 \\
\hline & 90.84 & 1.31 & 21.5 & -0.20 \\
\hline & 93.02 & 1.57 & 22.6 & -0.17 \\
\hline & 95.21 & 1.59 & 22.6 & -0.36 \\
\hline & 97.40 & 1.49 & 22.2 & -0.47 \\
\hline & 98.49 & 1.66 & 22.9 & -0.44 \\
\hline
\end{tabular}




\begin{tabular}{|c|c|c|c|}
\hline 99.58 & 1.56 & 22.5 & -0.60 \\
\hline 101.77 & 1.54 & 22.4 & -0.60 \\
\hline 103.95 & 1.45 & 22.1 & -0.75 \\
\hline 106.14 & 1.58 & 22.6 & -0.90 \\
\hline 108.33 & 1.69 & 23.0 & -0.74 \\
\hline 111.60 & 1.57 & 22.6 & -0.56 \\
\hline 112.70 & 1.55 & 22.5 & -0.58 \\
\hline 114.88 & 1.88 & 23.7 & -0.43 \\
\hline 117.07 & 1.88 & 23.7 & -0.91 \\
\hline 119.26 & 1.82 & 23.5 & -0.85 \\
\hline 121.44 & 2.14 & 24.6 & -0.91 \\
\hline 123.63 & 1.71 & 23.1 & -0.85 \\
\hline 125.81 & 2.03 & 24.2 & -0.90 \\
\hline 128.00 & 2.07 & 24.4 & -0.56 \\
\hline 129.88 & 2.19 & 24.8 & 0.01 \\
\hline 131.76 & 1.88 & 23.7 & 0.15 \\
\hline 133.63 & 1.96 & 24.0 & 0.23 \\
\hline 135.51 & 2.20 & 24.8 & 0.35 \\
\hline 137.39 & 1.84 & 23.6 & 0.14 \\
\hline 139.27 & 1.73 & 23.2 & 0.22 \\
\hline 141.15 & 1.93 & 23.9 & 0.31 \\
\hline 143.02 & 1.85 & 23.6 & 0.18 \\
\hline 144.90 & 1.90 & 23.8 & 0.08 \\
\hline 146.78 & 1.94 & 23.9 & 0.08 \\
\hline 148.66 & 1.87 & 23.7 & 0.11 \\
\hline 150.53 & 1.84 & 23.6 & 0.09 \\
\hline 152.41 & 1.93 & 23.9 & 0.42 \\
\hline 154.29 & 2.04 & 24.3 & 0.44 \\
\hline 156.17 & 1.91 & 23.8 & 0.49 \\
\hline 158.05 & 1.95 & 24.0 & 0.46 \\
\hline 159.92 & 2.14 & 24.6 & 0.43 \\
\hline 161.80 & 2.33 & 25.2 & -0.04 \\
\hline 163.68 & 2.10 & 24.5 & 0.22 \\
\hline 165.56 & 2.18 & 24.7 & 0.06 \\
\hline 167.44 & 2.10 & 24.5 & -0.10 \\
\hline 169.31 & 1.84 & 23.6 & -0.23 \\
\hline 171.19 & 1.91 & 23.8 & -0.41 \\
\hline 173.07 & 1.71 & 23.1 & -0.19 \\
\hline 174.95 & 1.75 & 23.2 & -0.54 \\
\hline 176.82 & 2.10 & 24.5 & -0.30 \\
\hline 178.70 & 2.22 & 24.9 & -0.42 \\
\hline 180.58 & 1.95 & 24.0 & -0.35 \\
\hline 182.46 & 1.96 & 24.0 & -0.18 \\
\hline
\end{tabular}

\section{Table 2 Caption}

Trace elements were analyzed on planktonic foraminifera Globigerinoides sacculifer (without the terminal sac), picked from the (250-350 $\mu \mathrm{m})$ fraction, and measured using a Varian ${ }^{\circledR}$ simultaneous ICP-AES. Calcite $\mathrm{Mg} / \mathrm{Ca}$ was translated into temperature using the calibration of (Dekens et al., 2001), which also takes into account dissolution by incorporating depth of deposition. The planktonic foraminifera $\delta^{18} \mathrm{O}$ follow procedures in caption of Table 1. All measurements were made at The Godwin Laboratory for Palaeoclimate Research, Department of Earth Sciences, University of Cambridge. 


\section{Table 3 - Radiocarbon Dates}

\begin{tabular}{lrrrrrrr}
$\begin{array}{c}\text { Depth } \\
(\mathbf{c m})\end{array}$ & \multicolumn{10}{c}{$\begin{array}{c}{ }^{14} \text { C age } \\
\text { Age (cal- }\end{array}$} & $\begin{array}{c}\text { Age } \\
\text { yr B.P.) }\end{array}$ & error & type \\
& SUERC-13140 & 3727 & 35 & 4077 & 4557 & 54 & sacculifer \\
& SUERC-13141 & 6039 & 35 & 6389 & 7313 & 45 & sacculifer \\
& SUERC-13142 & 9170 & 35 & 9520 & 10801 & 69 & sacculifer \\
& SUERC-13143 & 9038 & 35 & 9388 & 10608 & 15 & sacculifer \\
& SUERC-13144 & 11896 & 38 & 12246 & 14035 & 50 & sacculifer \\
SUERC-13147 & 13048 & 39 & 13398 & 15599 & 109 & sacculifer \\
SUERC-13148 & 14341 & 43 & 14691 & 17483 & 120 & sacculifer \\
SUERC-13149 & 14117 & 42 & 14467 & 17070 & 120 & sacculifer \\
SUERC-13150 & 14909 & 44 & 15259 & 18512 & 163 & sacculifer \\
SUERC-13665 & 17841 & 61 & 18191 & 21661 & 126 & sacculifer \\
SUERC-13668 & 18721 & 67 & 19071 & 22648 & 85 & ruber \\
LUKE to fill in & 21580 & 80 & 21930 & 26388 & 132 & menardii \\
SUERC-13669 & 22409 & 94 & 22759 & 27334 & 166 & sacculifer \\
SUERC-13670 & 23051 & 100 & 23401 & 28061 & 180 & ruber \\
SUERC-13671 & 28849 & 189 & 29199 & 34617 & 241 & ruber
\end{tabular}

\section{Table 3 Caption}

Radiocarbon analysis of planktonic foraminifera at the Scottish Universities Environmental Research Centre (SUERC) AMS Facility (5MV NEC AMS), with the exception of sample at $58 \mathrm{~cm}$ (denoted by *) which was picked by Luke Skinner and run by Stewart Fallon (more info from Luke to follow?). SUERC analysis were funded by grant allocation 1198.1006. Samples were hydrolysed to $\mathrm{CO}_{2}$ using $85 \%$ orthophosphoric acid at $25^{\circ} \mathrm{C}$. The gas was converted to graphite by Fe/Zn reduction. The errors are reported as $1 \sigma$. Conversion applied a uniform 350 y reservoir correction ((Butzin et al., 2005; Cao et al., 2007) and http://radiocarbon.LDEO.columbia.edu) and converted to calendar years using the Fairbanks calibration curve 01.07 (Fairbanks et al., 2005). 
Table 4 - Nd isotopes on Fe-Mn leachates

\begin{tabular}{|c|c|c|c|c|c|c|}
\hline $\begin{array}{r}\text { Depth } \\
(\mathbf{c m})\end{array}$ & Age (kyr) & $\begin{array}{c}\text { Number } \\
\text { of } \\
\text { analysis }\end{array}$ & ${ }^{143} \mathrm{Nd} /{ }^{144} \mathrm{Nd}$ & $\begin{array}{r}\text { internal } \\
\text { error }\end{array}$ & $\varepsilon_{\mathrm{Nd}}$ & $\begin{array}{l}\text { combined } \\
\text { error }\end{array}$ \\
\hline & 4.56 & 4 & 0.512149 & 3 & -9.54 & 0.20 \\
\hline & 5.57 & 3 & 0.512133 & 4 & -9.84 & 0.32 \\
\hline & 6.73 & 2 & 0.512165 & 5 & -9.22 & 0.24 \\
\hline & 8.48 & 2 & 0.512189 & 5 & -8.76 & 0.20 \\
\hline & 10.80 & 2 & 0.512208 & 5 & -8.39 & 0.24 \\
\hline & 10.80 & 2 & 0.512205 & 5 & -8.45 & 0.36 \\
\hline & 12.19 & 3 & 0.512204 & 3 & -8.46 & 0.20 \\
\hline & 14.04 & 2 & 0.512261 & 5 & -7.35 & 0.24 \\
\hline & 15.60 & 5 & 0.512262 & 2 & -7.33 & 0.19 \\
\hline & 17.74 & 4 & 0.512290 & 3 & -6.79 & 0.19 \\
\hline & 18.51 & 3 & 0.512300 & 6 & -6.60 & 0.24 \\
\hline & 18.51 & 2 & 0.512294 & 4 & -6.70 & 0.21 \\
\hline & 22.65 & 2 & 0.512318 & 3 & -6.25 & 0.24 \\
\hline & 25.14 & 2 & 0.512286 & 5 & -6.87 & 0.21 \\
\hline & 26.38 & 1 & 0.512314 & 7 & -6.32 & 0.25 \\
\hline & 26.70 & 2 & 0.512307 & 3 & -6.46 & 0.24 \\
\hline & 27.02 & 2 & 0.512286 & 5 & -6.86 & 0.25 \\
\hline & 27.50 & 3 & 0.512258 & 2 & -7.42 & 0.20 \\
\hline & 28.99 & 1 & 0.512301 & 10 & -6.57 & 0.25 \\
\hline & 29.93 & 1 & 0.512300 & 9 & -6.60 & 0.25 \\
\hline & 30.87 & 3 & 0.512248 & 4 & -7.60 & 0.22 \\
\hline & 32.74 & 3 & 0.512259 & 3 & -7.39 & 0.20 \\
\hline & 33.68 & 2 & 0.512284 & 4 & -6.90 & 0.25 \\
\hline & 34.62 & 1 & 0.512270 & 7 & -7.18 & 0.25 \\
\hline & 34.62 & 1 & 0.512318 & 14 & -6.24 & 0.25 \\
\hline & 35.69 & 1 & 0.512278 & 10 & -7.03 & 0.25 \\
\hline & 36.76 & 2 & 0.512280 & 3 & -6.99 & 0.24 \\
\hline & 38.91 & 3 & 0.512243 & 3 & -7.70 & 0.20 \\
\hline & 41.05 & 2 & 0.512263 & 8 & -7.31 & 0.21 \\
\hline & 42.12 & 1 & 0.512283 & 5 & -6.94 & 0.25 \\
\hline & 43.19 & 1 & 0.512275 & 5 & -7.07 & 0.25 \\
\hline & 44.27 & 3 & 0.512267 & 4 & -7.23 & 0.20 \\
\hline & 45.34 & 1 & 0.512283 & 5 & -6.92 & 0.25 \\
\hline & 46.41 & 1 & 0.512294 & 8 & -6.70 & 0.25 \\
\hline & 47.48 & 2 & 0.512279 & 4 & -7.00 & 0.24 \\
\hline & 48.55 & 1 & 0.512266 & 6 & -7.26 & 0.25 \\
\hline & 49.63 & 3 & 0.512242 & 3 & -7.73 & 0.20 \\
\hline & 50.70 & 1 & 0.512241 & 8 & -7.74 & 0.25 \\
\hline & 51.77 & 4 & 0.512220 & 3 & -8.16 & 0.23 \\
\hline & 52.84 & 1 & 0.512253 & 5 & -7.51 & 0.25 \\
\hline & 53.92 & 3 & 0.512231 & 3 & -7.94 & 0.20 \\
\hline & 54.99 & 2 & 0.512287 & 5 & -6.84 & 0.36 \\
\hline & 56.06 & 1 & 0.512264 & 5 & -7.30 & 0.25 \\
\hline
\end{tabular}




$\begin{array}{rrrrrr}59.28 & 2 & 0.512263 & 3 & -7.31 & 0.24 \\ 63.57 & 2 & 0.512252 & 5 & -7.53 & 0.21 \\ 67.86 & 2 & 0.512250 & 5 & -7.56 & 0.18 \\ 71.69 & 2 & 0.512268 & 3 & -7.22 & 0.24 \\ 73.38 & 3 & 0.512212 & 3 & -8.30 & 0.18 \\ 75.92 & 3 & 0.512221 & 4 & -8.14 & 0.22 \\ 77.62 & 2 & 0.512179 & 4 & -8.96 & 0.18 \\ 83.17 & 2 & 0.512175 & 3 & -9.03 & 0.18 \\ 89.74 & 3 & 0.512182 & 3 & -8.90 & 0.20 \\ 94.12 & 3 & 0.512177 & 3 & -8.99 & 0.20 \\ 102.86 & 2 & 0.512169 & 2 & -9.15 & 0.24 \\ 102.86 & 3 & 0.512173 & 4 & -9.07 & 0.22 \\ 105.05 & 3 & 0.512164 & 2 & -9.24 & 0.20 \\ 107.23 & 1 & 0.512178 & 11 & -8.98 & 0.25 \\ 109.42 & 3 & 0.512194 & 3 & -8.66 & 0.24 \\ 112.69 & 2 & 0.512202 & 2 & -8.50 & 0.24 \\ 114.88 & 3 & 0.512212 & 3 & -8.32 & 0.20 \\ 117.07 & 2 & 0.512205 & 3 & -8.45 & 0.24 \\ 119.26 & 3 & 0.512168 & 2 & -9.18 & 0.20 \\ 119.26 & 5 & 0.512187 & 3 & -8.80 & 0.23 \\ 121.44 & 3 & 0.512200 & 2 & -8.55 & 0.20 \\ 121.44 & 1 & 0.512194 & 4 & -8.67 & 0.22 \\ 124.54 & 3 & 0.512212 & 4 & -8.32 & 0.22 \\ 124.72 & 3 & 0.512203 & 2 & -8.49 & 0.20 \\ 125.81 & 1 & 0.512197 & 8 & -8.61 & 0.25 \\ 126.91 & 3 & 0.512257 & 3 & -7.43 & 0.20 \\ 128.00 & 1 & 0.512286 & 11 & -6.86 & 0.25 \\ 128.94 & 3 & 0.512194 & 3 & -7.30 & 0.22 \\ 129.87 & 1 & 0.512329 & 6 & -6.03 & 0.22 \\ 131.76 & 3 & 0.512266 & 2 & -7.26 & 0.24 \\ 132.69 & 1 & 0.512281 & 10 & -6.97 & 0.25 \\ 138.33 & 3 & 0.512311 & 3 & -6.38 & 0.20 \\ 140.21 & 3 & 0.512266 & 2 & -7.25 & 0.24 \\ 140.21 & 1 & 0.512264 & 3 & -7.29 & 0.22 \\ 142.08 & 3 & 0.512295 & 4 & -6.70 & 0.20 \\ 143.96 & 3 & 0.512266 & 2 & -7.26 & 0.24 \\ 143.96 & 1 & 0.512259 & 4 & -7.39 & 0.22 \\ 153.35 & 1 & 0.512316 & 7 & -6.28 & 0.25\end{array}$

\section{Table 4 Caption}

Neodymium isotopes were analyzed by $\mathrm{Nu}$ Plasma HR multi-collector plasma mass spectrometer (MC-ICPMS) at the University of Cambridge, using bracketing of JNdi-1 for standard correction. Reported ${ }^{143} \mathrm{Nd} /{ }^{144} \mathrm{Nd}$ are often averages of multiple runs, each for 40 ratios, and the error reported is the internal error on the analysis $(2 \sigma)$. The reported $\varepsilon_{\mathrm{Nd}}$ is an average of multiple runs, and the combined internal and external error $(2 \sigma)$. Total procedural replicates are denoted by asterisks. 


\section{Figure 1.}

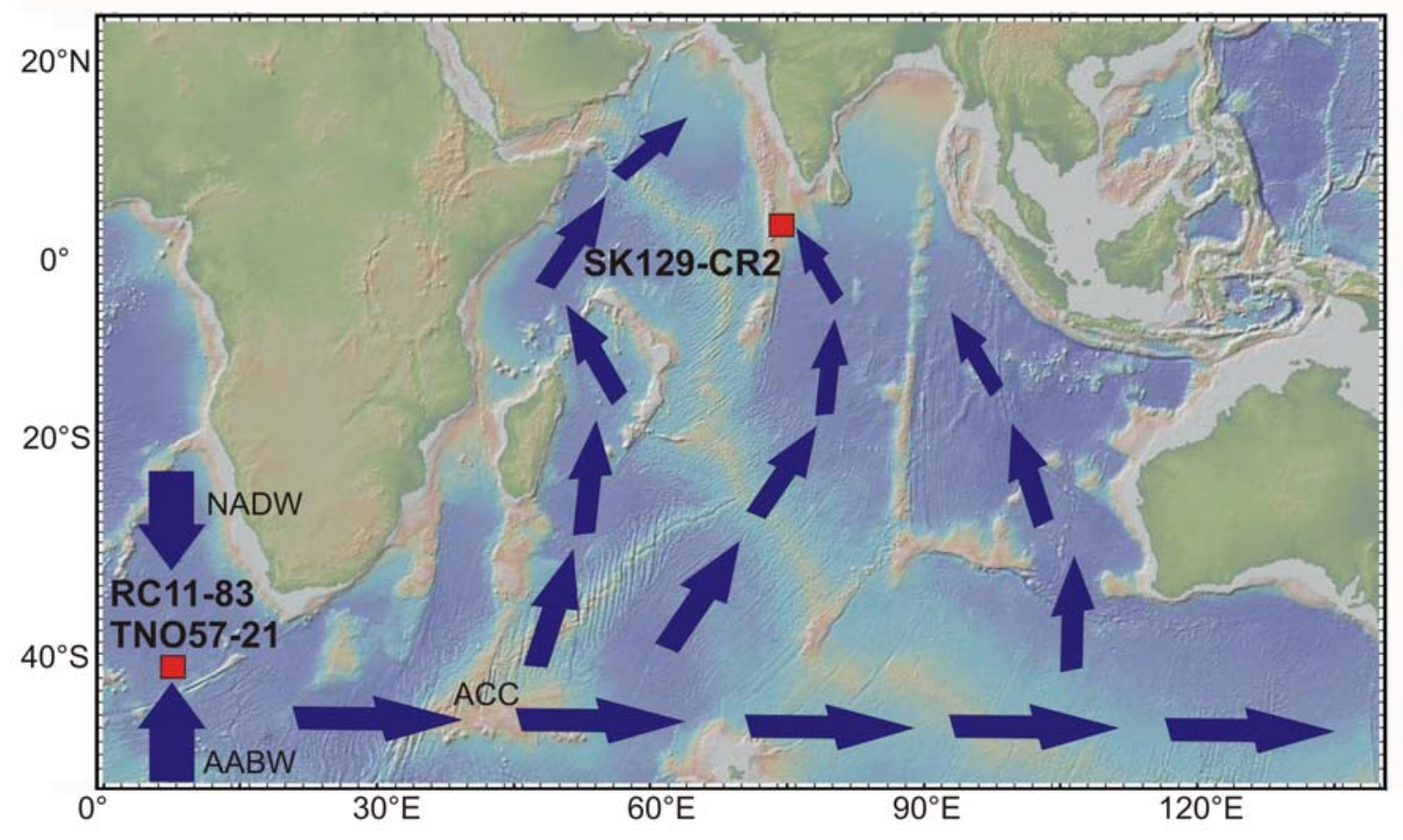


Figure 2.

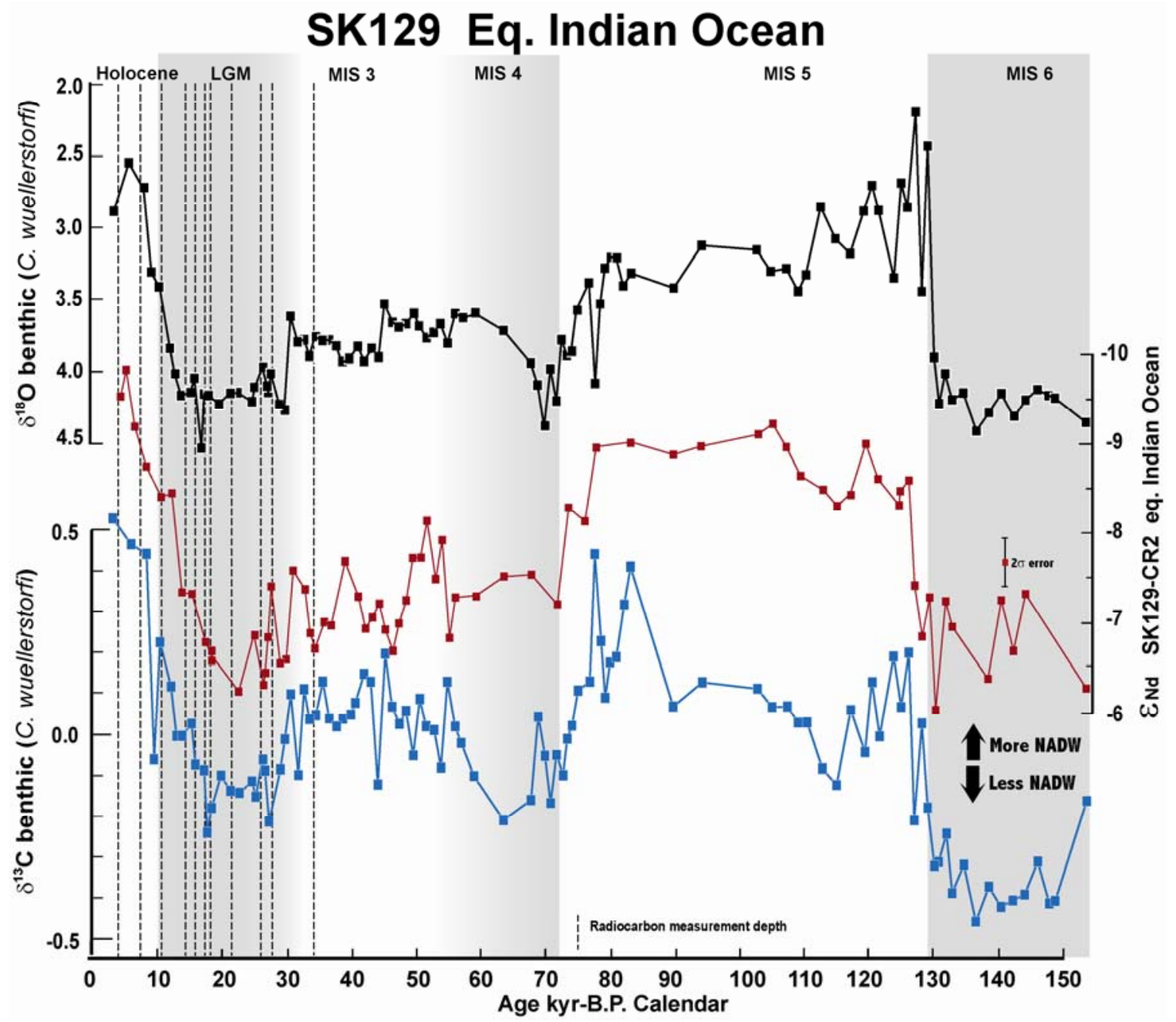


Figure 3.

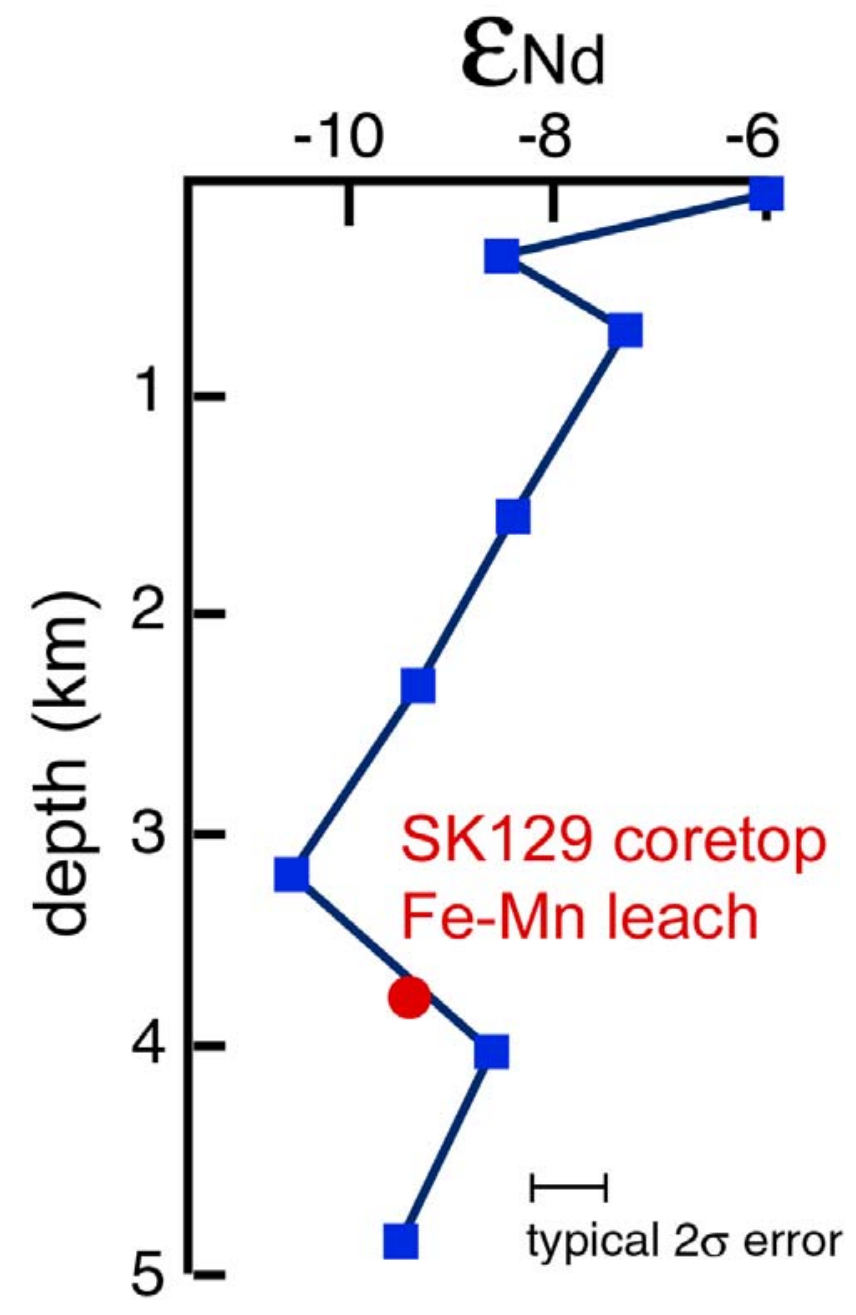




\section{Figure 4.}

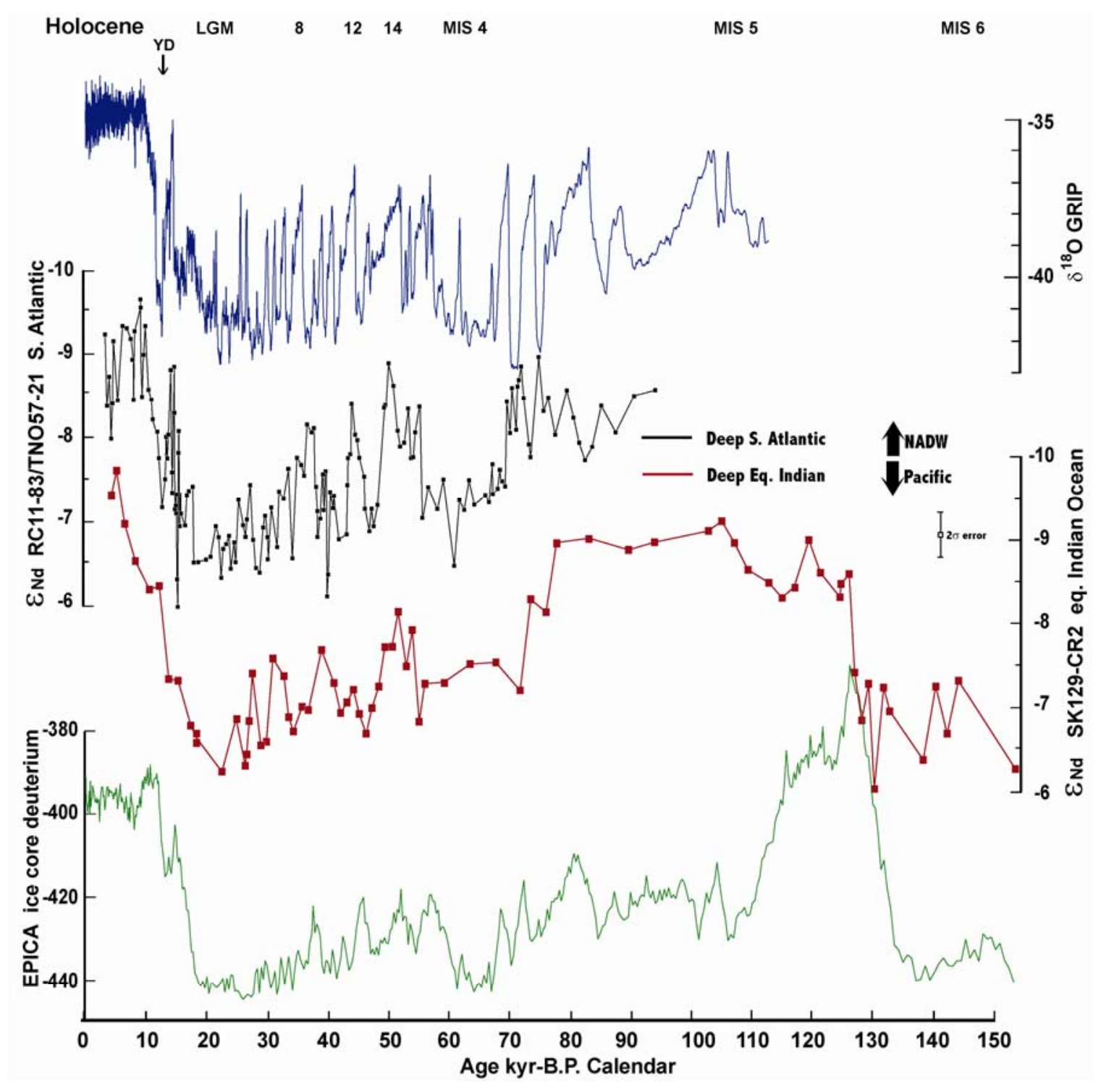


Figure 5.

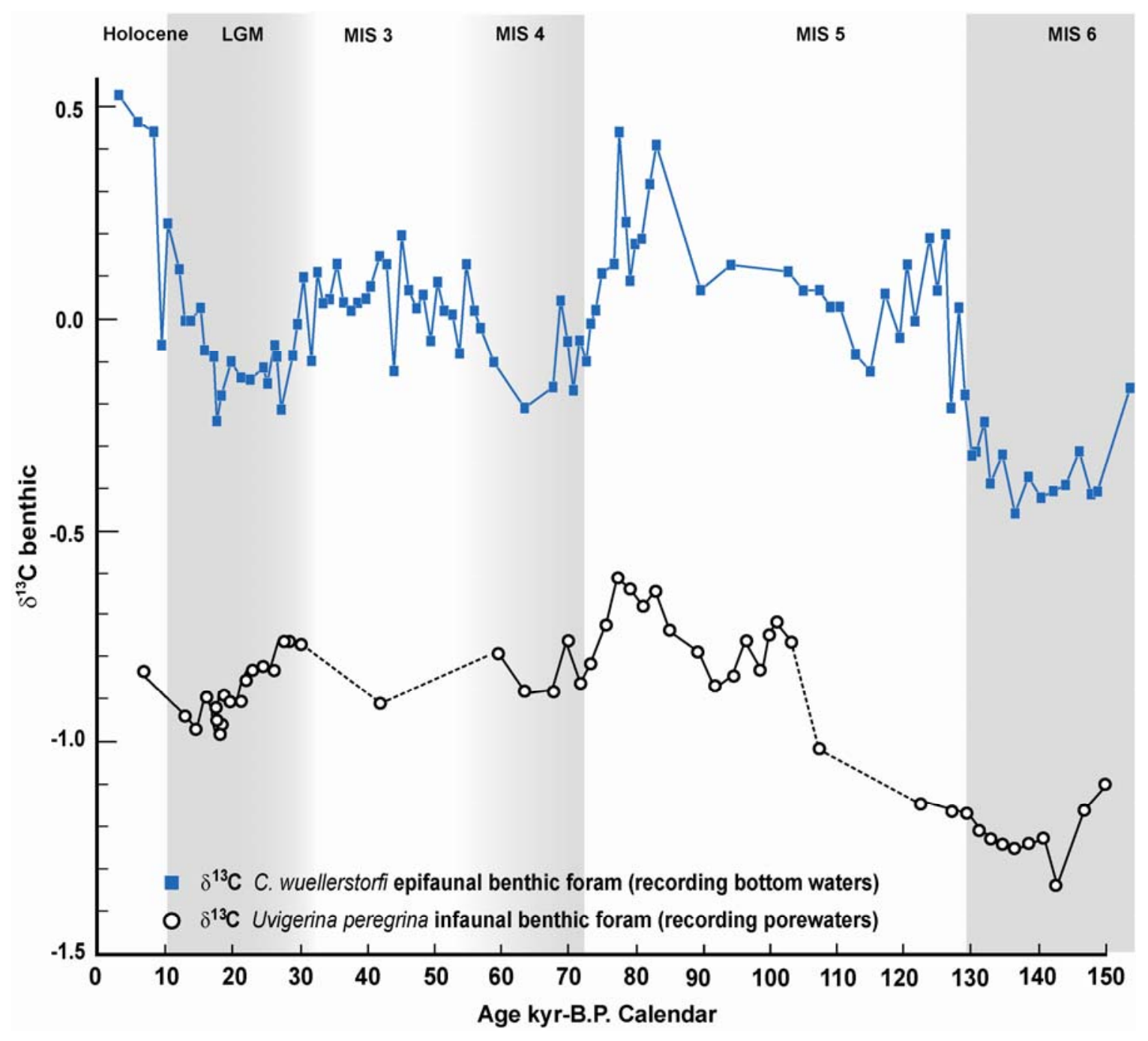


Figure 6.

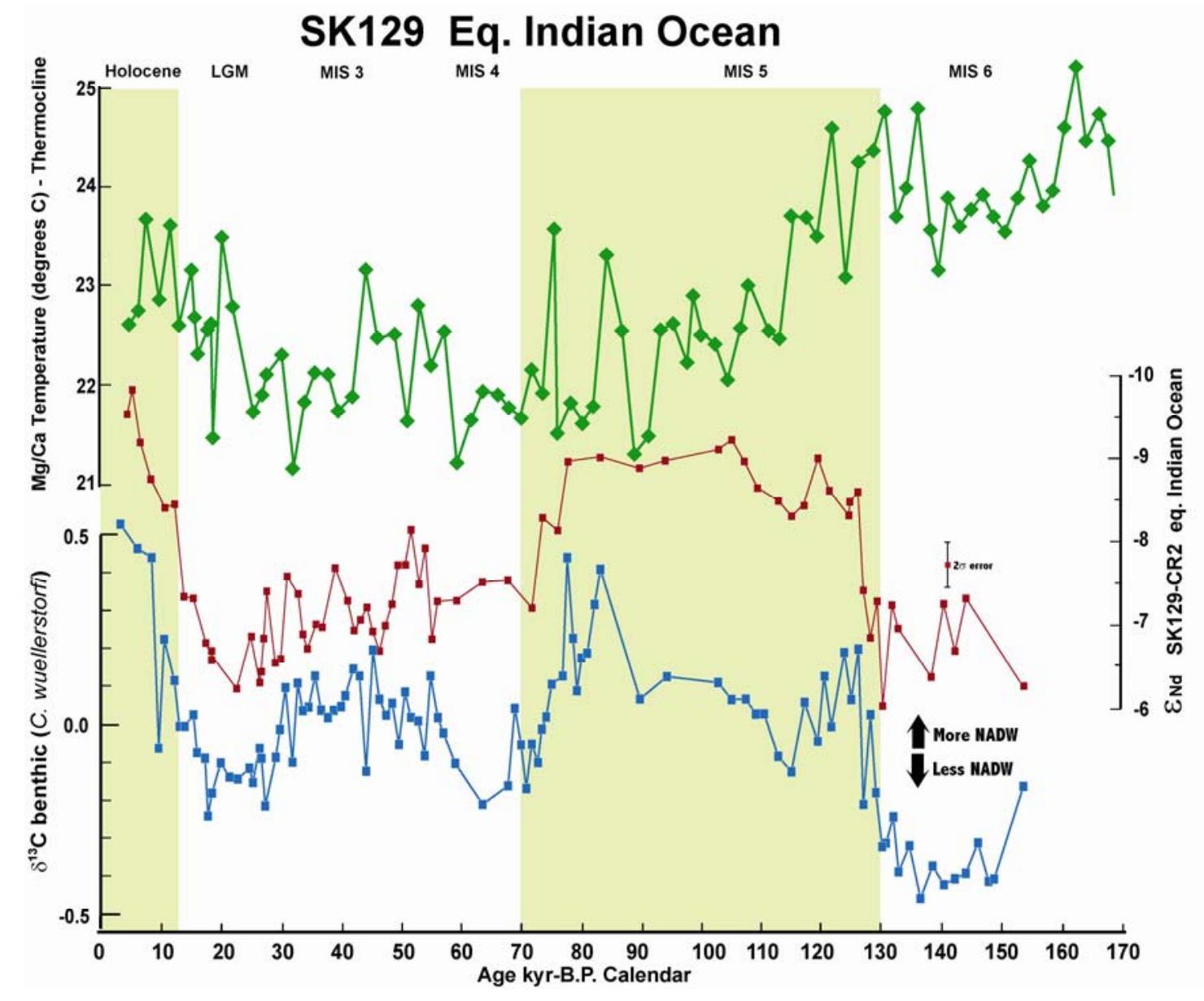


Figure 7.

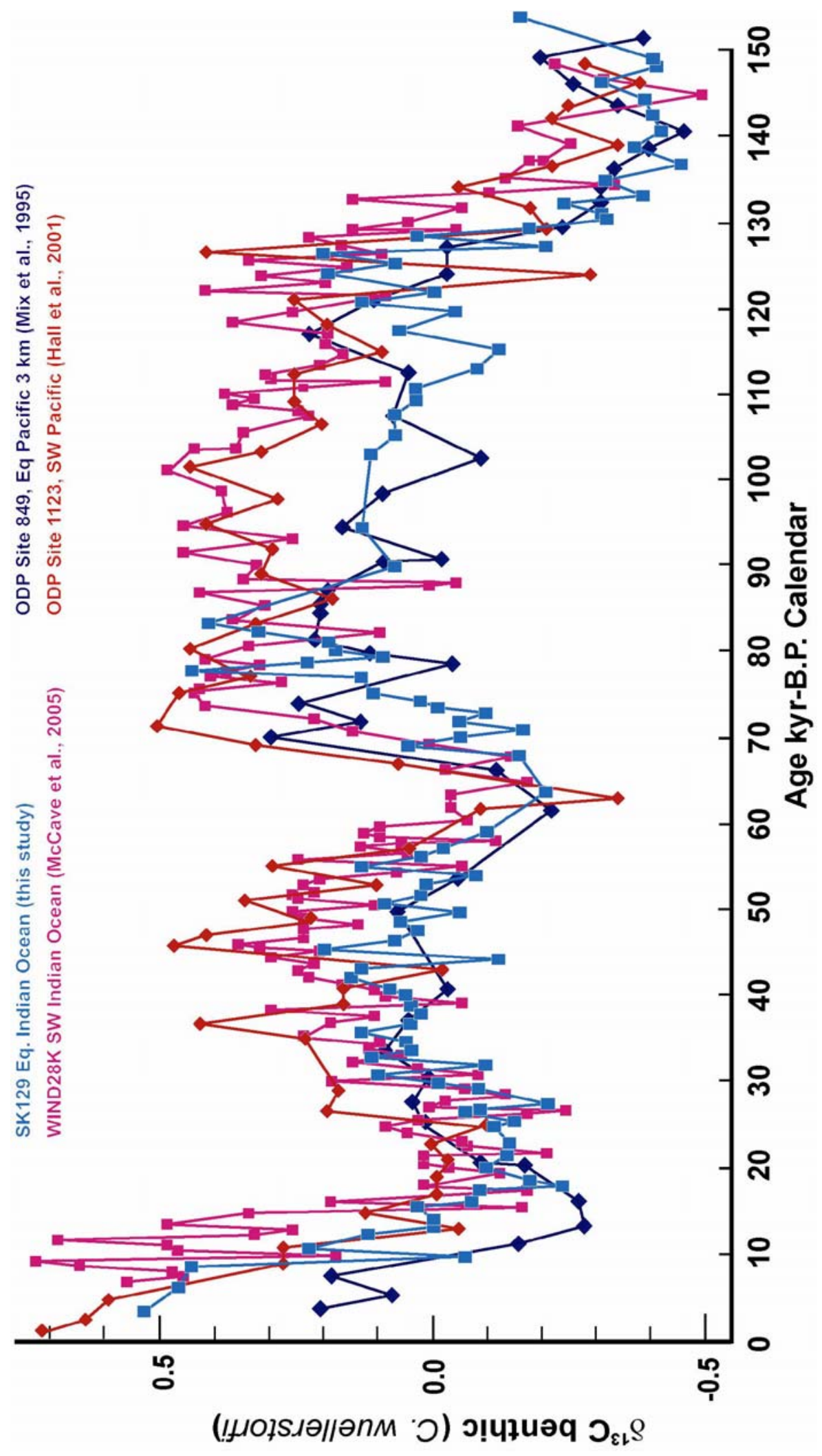




\section{Figure Captions}

Figure 1 - Map of general Indian Ocean deep circulation and location of Core SK129-CR2 $\left(3^{\circ} \mathrm{N}, 76^{\circ} \mathrm{E}, 3800 \mathrm{~m}\right.$ b.s.l.). The location of South Atlantic Cape Basin cores TNO57-21 and RC11-83, to which comparison of the Indian ocean $\mathrm{Nd}$ isotope record is made, are also denoted.

Figure 2 - Epifaunal benthic foraminifera Cibicidoides wuellerstorfi $\delta^{13} \mathrm{C}$ (blue) and $\delta^{18} \mathrm{O}$ (black) records and Neodymium isotope record on Fe-Mn leachates (red). Chronology is based on radiocarbon dates (Table 3), denoted as dashed lines, and $\delta^{18} \mathrm{O}$ stratigraphy using the MIS 5-4 and MIS 6-5 boundaries. For the $\delta^{18} \mathrm{O}$ and $\mathrm{Nd}$ records, the axis has been reversed for easy comparison to other paleoclimate records.

Figure 3 - The $\varepsilon_{\mathrm{Nd}}$ of the Fe-Mn leachate from the core-top section (at $2.5 \mathrm{~cm}$ depth) of SK129-CR2 (dated to $4.56 \mathrm{kyr}$ calendar BP) is denoted by the red point. The nearest Nd isotope seawater measurement from a Somali Basin profile (from site CD-1507 at 06 $09.2 \mathrm{~S}, 50^{\circ} 53.7 \mathrm{E}$ ) (Bertram and Elderfield, 1993) is shown by the blue squares.

Figure 4 - Comparison of the SK129-CR2 Nd isotope record (red) to Greenland (GRIP) oxygen and Antarctic (Vostok) deuterium records, interpreted as reflecting paleotemperature changes. Also comparison is made to the South Atlantic Cape Basin cores TNO57-21 and RC11-83 Nd isotope record (black) (Piotrowski et al., 2005). For the $\mathrm{Nd}$ records, the axis has been reversed for easy comparison to other paleoclimate records.

Figure 5 - Comparison of epifaunal benthic foraminifera Cibicidoides wuellerstorfi $\delta^{13} \mathrm{C}$ (blue), taken as recording past bottom water $\delta^{13} \mathrm{C}$ changes, with infaunal Uvigerina 
peregrina $\delta^{13} \mathrm{C}$ (black circles) (Banakar, 2005), taken as recording past porewater $\delta^{13} \mathrm{C}$ changes.

Figure 6 - Nd isotopes from Fe-Mn oxide leachates (red) compared to epifaunal benthic foraminifera Cibicidoides wuellerstorfi $\delta^{13} \mathrm{C}$ (blue) and thermocline temperature from planktonic foraminifera Globigerinoides sacculifer (without the terminal sac), picked from the $(250-350 \mu \mathrm{m})$ fraction. Interglacial conditions are denoted with the yellow banding.

Figure 7 - Comparison of Indian Ocean and Pacific $\delta^{13} \mathrm{C}$ gradients. Southwestern Indian Ocean site $\delta^{13} \mathrm{C}$ record (WIND28K) (McCave et al., 2005) and Southwestern Pacific site $\delta^{13} \mathrm{C}$ record (ODP Site 1123) (Hall et al., 2001), both sampling inflow to these ocean basins, are pink and red, respectively. Equatorial Indian Ocean $\delta^{13} \mathrm{C}$ record (SK129-CR2), this study, and equatorial Pacific $\delta^{13} \mathrm{C}$ record (ODP Site 849) (Mix and al, 1995), which monitor more nutrient rich waters are light blue and dark blue respectively. This plot follows the analysis in (Hall et al., 2001). All were measured on Cibicidoides wuellerstorfi $\delta^{13} \mathrm{C}$ except ODP Site 1123 which was measured on Uvigerina peregrina and has been converted to Cibicidoides wuellerstorfi values by adjusting by $+0.9 \%$ (Hall et al., 2001). 


\section{References}

Adkins, J., McIntyre, K. and Schrag, D.P., 2002. The temperature, salinity, and delta O-18 of the LGM ocean. Science, 298(5599): 1769-1773.

Amakawa, H., Sasaki, K. and Ebihara, M., 2006. Nd isotopic composition of the Northcentral Pacific Ocean, The 16th Annual V.M. Goldschmidt Conference. Geochimica et Cosmochimica Acta, Melbourne Australia, pp. A13-A13.

Arsouze, T., Dutay, J.C., Lacan, F. and Jeandel, C., 2007. Modeling the neodymium isotopic composition with a global cirulation model. Chemical Geology, 239(1-2): 165-177.

Banakar, V.K., 2005. Delta C-13 depleted oceans before the Termination 2: More nutrientrich deep-water formation of light-carbon transfer? Indian Journal of Marine Sciences, 34(3): 249-258.

Banakar, V.K., Galy, A., Sukumaran, N.P., Parthiban, G. and Volvaiker, A.Y., 2003. Himalayan sedimentary pulses recorded by silicate detritus within a ferromanganese crust from the Central Indian Ocean. Earth and Planetary Science Letters, 205: 337348.

Bayon, G., German, C., Burton, K., Nesbitt, R. and Rogers, N., 2003. Sedimentary Fe-Mn oxyhydroxides as paleoceanographic archives and the role of aeolian flux in regulating oceanic dissolved REE. Earth Planet. Sci. Letters., 224(3-4): 447-492.

Bayon, G. et al., 2002a. An improved method for extracting marine sediment fractions and its application to Sr and Nd isotopic analysis. Chem. Geology, 187: 179-199.

Bayon, G., German, C.R., Burton, K.W. and Nesbitt, R.W., 2002b. The role of aeolian dust in scavenging rare earth elements from the ocean. Geochim. Cosmochim. Acta, 66(15A): A57-A57.

Beaufort, L. et al., 1997. Insolation cycles as a major control of equatorial Indian Ocean primary production. Science, 278(1451): DOI 10.1126/science.278.5342.141.

Bertram, C.J. and Elderfield, H., 1993. The geochemical balance of the rare earth elements and neodymium isotopes in the oceans. Geochim. Cosmochim. Acta, 57: 19571986.

Boyle, E., 1995. Last-Glacial-Maximum North-Atlantic Deep-Water - on, off or Somewhere in-Between. Philosophical Transactions of the Royal Society of London Series B-Biological Sciences, 348(1324): 243-253.

Boyle, E.A., 1992. Cadmium and Delta-C-13 Paleochemical Ocean Distributions During the Stage-2 Glacial Maximum. Annual Review of Earth and Planetary Sciences, 20: 245-287.

Boyle, E.A. and Keigwin, L.D., 1985. Comparison of Atlantic and Pacific Paleochemical Records for the Last 215,000 Years - Changes in Deep Ocean Circulation and Chemical Inventories. Earth and Planetary Science Letters, 76(1-2): 135-150.

Broecker, W.S. and Denton, G.H., 1989. The role of ocean-atmosphere reorganizations in Glacial Cycles. Geochim. Cosmochim. Acta., 53(10): 2465-2501.

Butzin, M., Prange, M. and Lohmann, G., 2005. Radiocarbon simulations for the glacial ocean: the effects of wind stress, Southern Ocean sea ice and Heinrich Events. Earth and Planetary Science Letters, 235: 45-61. 
Cao, L., Fairbanks, R.G., Mortlock, R. and Risk, M.J., 2007. Radiocarbon reservoir age of high latitude North Atlantic surface water during the last deglacial. Quaternary Sci. Rev., 26(5-6): 732-742.

Charles, C.D. and Fairbanks, R.G., 1992. Evidence from Southern-Ocean Sediments for the Effect of North-Atlantic Deep-Water Flux on Climate. Nature, 355(6359): 416-419.

Charles, C.D., Lynch-Stieglitz, J., Ninnemann, U.S. and Fairbanks, R.G., 1996. Climate connections between the hemispheres revealed by deep sea sediment core ice core correlations. Earth and Planetary Science Letters, 142(1-2): 19-27.

Chester, R. and Hughes, M.J., 1967. A chemical technique for the separation of ferromanganese minerals, carbonate minerals and adsorbed trace Elements from pelagic sediments. Chem. Geol., 2: 249-262.

Curry, W. and Oppo, D., 2005. Glacial water mass geometry and the distribution of 13C of TCO2 in the western Atlantic Ocean. Paleoceanography, 20: PA1017.

Curry, W.B., Duplessy, J.C., Labeyrie, L.D., and Shackleton, N.J., 1988. Changes in the distribution of $\mathrm{d} 13 \mathrm{C}$ of deep water TCO2 between the last glaciation and the Holocene. Paleoceanography, 3(3): 317-341.

Dekens, P.S., Lea, D.W., Pak, D.K. and Spero, H.J., 2001. Core-top calibration of Mg/Ca in tropical foraminifera: refining paleo-temperature estimation. Geochemistry Geophysics Geosystems, 3(doi: 10.1029/2001GC000200).

Duplessy, J.C. et al., 1988. Deepwater source variations during the last climatic cycle and their impact on the global deepwater circulation. Paleoceanography, 3(3): 343-360.

Eggins, S., DeDekker, P. and Marshall, J., 2003. Mg/Ca variations in planktonic foraminifera tests: implications for reconstructing palaeo-seawater temperature and habitat migration. Earth and Planetary Science Letters, 212(3-4): 291-306.

Elderfield, H. and Ganssen, G., 2000. Past temperature and delta 18-O of surface ocean waters inferred from foraminiferal Mg/Ca ratios. Nature, 405(6785): 442-445.

Fairbanks, R.G. et al., 2005. Marine radiocarbon calibration curvespanning 10000 to 50000 years BP based on paired 230Th/234U/238U and 14C dates on pristine corals. Quaternary Science Reviews, 24: 1781-1796.

Frank, M., 2002. Radiogenic isotopes: Tracers of past ocean circulation and erosional input. Reviews of Geophysics, 40(1): art. no. 1001.

Ganopolski, A. and Rahmstorf, S., 2001. Rapid changes of glacial climate simulated in a coupled climate model. Nature, 409(6817): 153-158.

Goldstein, S.L. and Hemming, S.R., 2003. Long-lived Isotopic Tracers in Oceanography, Paleoceanography and Ice Sheet Dynamics. In: H. Elderfield (Editor), Treatise on Geochemistry. Elsevier, Oxford, pp. 453-489.

Gourlan, A.T., Meynadier, L. and Allegre, C.J., 2008. Tectonically driven changes in the Indian Ocean circulation over the last $25 \mathrm{Ma}$ : neodymium isotope evidence. Earth and Planetary Science Letters, 267(353-364).

Gutjahr, M. et al., 2007. Reliable extraction of a deepwater trace metal isotope signal from Fe-Mn oxyhydroxide coatings of marine sediments. Chemical Geology, 242(3-4): 351-370.

Hall, I.R., McCave, I.N., Shackleton, N.J., Weedon, G.P. and Harris, S.E., 2001. Intensified deep Pacfic inflow and ventilation in Pleistocene glacial times. Nature, 412(6849): 809-812. 
Ivanochko, T.S. et al., 2005. Variations in tropic convection as an amplifier of global climate change at the millennial scale. Earth and Planetary Science Letters, 235: 302-314.

Jacobsen, S.B. and Wasserburg, G.J., 1980. Sm-Nd Isotopic Systematics of Chondrites and Achondrites. Meteoritics, 15(4): 307-308.

Jeandel, C., Bishop, J.K. and Zindler, A., 1995. Exchange of Neodymium and Its Isotopes between Seawater and Small and Large Particles in the Sargasso Sea. Geochimica Et Cosmochimica Acta, 59(3): 535-547.

Jeandel, C., Pradoux, K., Lacan, F. and Provost, C., 2008. Nd isotopic signatures of Drake Passage water masses, 18th Annual V.M. Goldschmidt Conference. Geochimica et Cosmochimica Acta, Vancouver, Canada, pp. A425-A425.

Jeandel, C., Thouron, D. and Fieux, M., 1998. Concentrations and isotopic compositions of neodymium in the eastern Indian Ocean and Indonesian straits. Geochimica Et Cosmochimica Acta, 62(15): 2597-2607.

Jones, C.E., Halliday, A.N., Rea, D.K. and Owen, R.M., 1994. Neodymium isotopic variations in North Pacific modern silicate sediment and the insignificance of detrital REE contributions to seawater. Earth Planet. Sci. Lett., 127: 55-66.

Jones, K.M., Khatiwala, S.P., Goldstein, S.L., Hemming, S.R. and van de Flierdt, T., 2008. Modeling the distribution of $\mathrm{Nd}$ isotopes in the oceans using a general circulation model. Earth and Planetary Science Letters, 272(3-4): 610-619.

Kroopnick, P.M., 1985. The distribution of C-13 of Sigma-CO2 in the world ocean. Deep Sea Research A-Oceanographic Research Papers, 32(1): 57-84.

Lacan, F. and Jeandel, C., 2005. Acquisition of the neodymium isotopic composition of the North Atlantic Deep Water. Geochemistry Geophysics Geosystems, 6(12): Q12008, doi:10.1029/2005GC000956.

Lacan, F., Jeandel, C., 2004. Neodymium isotopic composition and rare earth element concentrations in the deep and intermediate Nordic Seas: Constraints on the Iceland Scotland Overflow Water signature. Geochemistry Geophysics Geosystems, 5(11): doi:10.1029/2004GC000742.

Lea, D.W., 1995. A Trace-Metal Perspective on the Evolution of Antarctic Circumpolar Deep-Water Chemistry. Paleoceanography, 10(4): 733-747.

Lynch-Steiglitz, J. and Fairbanks, R.G., 1994. A conservative tracer for glacial ocean circulation from carbon isotope and palaeo-nutrient measurements in benthic foraminifera. Nature, 369(26 May): 308-310.

Mackensen, A. and Douglas, R.G., 1989. Down-Core Distribution of Live and Dead DeepWater Benthic Foraminifera in Box Cores from the Weddell Sea and the California Continental Borderland. 36(6): 879-900.

Mackensen, A., Hubberten, H.W., Bickert, T., Fischer, G. and Futterer, D.K., 1993. The Delta-C-13 in Benthic Foraminiferal Tests of Fontbotia-Wuellerstorfi (Schwager) Relative to the Delta-C-13 of Dissolved Inorganic Carbon in Southern-Ocean DeepWater - Implications for Glacial Ocean Circulation Models. Paleoceanography, 8(5): 587-610.

Mackensen, A., Hubberten, H.W., Scheele, N. and Schlitzer, R., 1996. Decoupling of delta C-13(Sigma CO2) and phosphate in recent Weddell Sea deep and bottom water: Implications for glacial southern ocean paleoceanography. Paleoceanography, 11(2): 203-215. 
Mackensen, A., Schumacher, S., Radke, J. and Schmidt, D.N., 2000. Microhabitat preferences and stable carbon isotopes of endobenthic foraminifera: clue to quantitative reconstruction of oceanic new production? Mar. Micropaleontol., 40(3): 233-258.

Mahowald, N.M. et al., 2006. Change in atmospheric mineral aerosols in response to climate: last glacial period, preindustrial, modern, and doubled carbon dioxide climates. J. Geophys. Res. Atmos., 111(D10).

Marchitto, T.M., Lynch-Steiglitz, J. and Hemming, S.R., 2005. Deep Pacific CaCO3 compensation and glacial-interglacial atmospheric CO2. Earth and Planetary Science Letters, 231: 317-336.

Martinson, D.G. et al., 1987. Age Dating and the Orbital Theory of the Ice Ages Development of a High-Resolution-0 to 300,000-Year Chronostratigraphy. Quat. Research, 27(1): 1-29.

McCave, I.N., Kiefer, T., Thornalley, D.J.R. and Elderfield, H., 2005. Deep flow in the Madagascar-Mascarene Basin over the last 150000 years. Phil.Trans. R. Soc. Lond., 363: 81-99.

Mix, A.C. and al, e., 1995. Benthic foraminifer stable isotope record from Site 849 (0-5 $\mathrm{Ma}$ ): Local and global climate changes. Proceeding of the Ocean Drilling Program Scientific Results, 138: 371-412.

Naqvi, W.A., Charles, C.D. and Fairbanks, R.G., 1994. Carbon and Oxygen Isotopic Records of Benthic Foraminifera from the Northeast Indian-Ocean - Implications on Glacial-Interglacial Atmospheric CO2 Changes. Earth and Planetary Science Letters, 121(1-2): 99-110.

Piotrowski, A.M., Goldstein, S.L., Hemming, S.R. and Fairbanks, R.G., 2004. Intensity and variability of ocean thermohaline circulation during the last deglaciation. Earth Planet. Sci. Letters., 225: 205-220.

Piotrowski, A.M., Goldstein, S.L., Hemming, S.R. and Fairbanks, R.G., 2005. Temporal Relationships of Carbon Cycling and Ocean Circulation at Glacial Boundaries. Science, 307(5717): 1933-1938.

Piotrowski, A.M., Goldstein, S.L., Hemming, S.R., Fairbanks, R.G. and Zylberberg, D.R., 2008. Oscillating glacial northern and southern deep water formation from combined neodymium and carbon isotopes. Earth and Planetary Science Letters, 272: 394-405.

Rickaby, R.E.M., Greaves, M.J. and Elderfield, H., 2000. Cd in planktonic and benthic foraminiferal shells determined by thermal ionisation mass spectrometry. 64(7): 1229-1236.

Rutberg, R.L., Hemming, S.R. and Goldstein, S.L., 2000. Reduced North Atlantic Deep Water flux to the glacial Southern Ocean inferred from neodymium isotope ratios. Nature, 405(6789): 935-938.

Schott, F. and McCreary, J.P., 2001. The monsoon circulation of the Indian Ocean. Progress in Oceanography, 51: 1-123.

Sigman, D.M. and Boyle, E.A., 2000. Glacial/interglacial variations in atmospheric carbon dioxide. Nature, 407(6806): 859-869.

Sigman, D.M. and Boyle, E.A., 2001. Palaeoceanography - Antarctic stratification and glacial CO2 - Sigman and Boyle reply. Nature, 412(6847): 606-606. 
Sirocko, F., 1995. Abrupt Change in Monsoonal Climate; Evidence from the Geochemical Composition of Arabian Sea Sediments. Habilitation Thesis, Christian Albrecht University Kiel.

Stocker, T.F., 2000. Past and future reorganizations in the climate system. 19(1-5): 301319.

Stoll, H.M., Vance, D. and Arevalos, A., 2007. Records of the Nd isotope composition of seawater from the Bay of Bengal: Implications for the impact of Northern Hemisphere cooling on ITCZ movement. Earth and Planetary Science Letters, 255: 213-228.

Tachikawa, K., Athias, V. and Jeandel, C., 2003. Neodymium budget in the modern ocean and paleo-oceanographic implications. Journal of Geophysical Research-Oceans, 108(C8): Art. No. 3254.

Tachikawa, K., Jeandel, C. and Roy-Barman, M., 1999a. A new approach to the Nd residence time in the ocean: the role of atmospheric inputs. Earth and Planetary Science Letters, 170(4): 433-446.

Tachikawa, K., Jeandel, C., Vangriesheim, A. and Dupre, B., 1999b. Distribution of rare earth elements and neodymium isotopes in suspended particles of the tropical Atlantic Ocean (EUMELI site). Deep-Sea Research Part I-Oceanographic Research Papers, 46(5): 733-755.

Tanaka, T. et al., 2000. Ndi-1: a neodymium isotopic reference in consistency with LaJolla neodymium. Chem. Geology, 168: 279-281.

Thomas, A.L., Henderson, G.M. and McCave, I.N., 2007. Constant bottom water flow into the Indian Ocean for the past 140 ka indicated by sediment Pa-231/Th-230 ratios. Paleoceanography, 22(4): PA4210.

Thomas, A.L., Henderson, G.M. and Robinson, L.F., 2006. Interpretation of the 231Pa/230Th paleocirculation proxy: new water column measurements from the southwest Indian Ocean. Earth and Planetary Science Letters, 241: 493-504.

Thompson, P.R., Be, A.W.H., Duplessy, J.C. and Shackleton, N.J., 1979. Disappearance of pink-pigmented Globigerinoides ruber at 120000 yr BP in the Indian and Pacific Oceans. Nature, 280(554-558).

van de Flierdt, T. et al., 2004. Deep and bottom water export from the Southern Ocean to the Pacific over the past 38 million years. 19(1).

Waelbroeck, C. et al., 2006. Distant origins of circulation changes in the Indian Ocean during the last deglaciation. Earth and Planetary Science Letters, 243: 244-251. 